\title{
From Biomarkers to Models in the Changing Landscape of Chronic Lymphocytic Leukemia: Evolve or Become Extinct
}

\author{
Isabel González-Gascón-y-Marín ${ }^{1}$ **(D) Carolina Muñoz-Novas ${ }^{1}$, Ana-Eugenia Rodríguez-Vicente ${ }^{2}{ }^{(D}$, \\ Miguel Quijada-Álamo ${ }^{2}$, María Hernández-Sánchez ${ }^{2} \mathbb{D}$, Claudia Pérez-Carretero ${ }^{2} \mathbb{0}$, Victoria Ramos-Ascanio ${ }^{1}$ \\ and José-Ángel Hernández-Rivas ${ }^{1,3}$
}

1 Department of Hematology, Hospital Universitario Infanta Leonor, 28031 Madrid, Spain; carolinacecilia.munoz@salud.madrid.org (C.M.-N.); vramosa@salud.madrid.org (V.R.-A.); jahernandezr@salud.madrid.org (J.-Á.H.-R.)

2 Centro de Investigación del Cáncer, Department of Hematology, Hospital Universitario de Salamanca, Salamanca-CSIC University, IBSAL, IBMCC, 37007 Salamanca, Spain; anita82@usal.es (A.-E.R.-V.); mquijada@usal.es (M.Q.-Á.); mariahs@usal.es (M.H.-S.); claupeca@usal.es (C.P.-C.)

3 Facultad de Medicina, Universidad Complutense de Madrid, 28040 Madrid, Spain

* Correspondence: igonzalezg@salud.madrid.org

Citation: González-Gascón-y-Marín, I. Muñoz-Novas, C.; Rodríguez-Vicente, A.-E.; Quijada-Álamo, M.; Hernández-Sánchez, M.; Pérez-Carretero, C.; Ramos-Ascanio, V.; Hernández-Rivas, J.-Á. From Biomarkers to Models in the Changing Landscape of Chronic Lymphocytic Leukemia: Evolve or Become Extinct. Cancers 2021, 13, 1782. https://doi.org/ 10.3390/ cancers13081782

Academic Editors: Giuseppe Broggi and Lucia Salvatorelli

Received: 21 February 2021

Accepted: 5 April 2021

Published: 8 April 2021

Publisher's Note: MDPI stays neutral with regard to jurisdictional claims in published maps and institutional affiliations.

Copyright: (c) 2021 by the authors. Licensee MDPI, Basel, Switzerland. This article is an open access article distributed under the terms and conditions of the Creative Commons Attribution (CC BY) license (https:// creativecommons.org/licenses/by/ $4.0 /)$.
Simple Summary: Chronic lymphocytic leukemia (CLL) is characterized by a highly variable clinical course. Thus, predicting the outcome of patients with this disease is a topic of special interest. The rapidly changing treatment landscape of CLL has questioned the value of classical biomarkers and prognostic models. Herein we examine the current state-of-the-art of prognostic and predictive biomarkers in the setting of new oral targeted agents with special focus on the most controversial findings over the last years. We also discuss the available information on the role of "old" and "new" prognostic models in the era of oral small molecules.

Abstract: Chronic lymphocytic leukemia (CLL) is an extremely heterogeneous disease. With the advent of oral targeted agents (Tas) the treatment of CLL has undergone a revolution, which has been accompanied by an improvement in patient's survival and quality of life. This paradigm shift also affects the value of prognostic and predictive biomarkers and prognostic models, most of them inherited from the chemoimmunotherapy era but with a different behavior with Tas. This review discusses: (i) the role of the most relevant prognostic and predictive biomarkers in the setting of Tas; and (ii) the validity of classic and new scoring systems in the context of Tas. In addition, a critical point of view about predictive biomarkers with special emphasis on 11q deletion, novel resistance mutations, TP53 abnormalities, IGHV mutational status, complex karyotype and NOTCH1 mutations is stated. We also go over prognostic models in early stage CLL such as IPS-E. Finally, we provide an overview of the applicability of the CLL-IPI for patients treated with Tas, as well as the emergence of new models, generated with data from patients treated with Tas.

Keywords: chronic lymphocytic leukemia; prognosis; targeted therapy

\section{Introduction}

Chronic lymphocytic leukemia (CLL) is the most frequent chronic leukemia in Western countries. The diagnosis is usually incidental in a routine blood test and its outcome is extremely heterogeneous. Some patients present with a rapidly progressive evolution, while others remain at an indolent state for the rest of their lives. Antitumor therapy is only required if active disease is documented, according to the International Workshop on Chronic Lymphocytic Leukemia (iwCLL) criteria [1]. Furthermore, response to treatment is also variable and may be predicted by different biomarkers. This is of vital importance at this time, in which treatment algorithms have drastically changed and chemoimmunotherapy (CIT) has been replaced by targeted agents (Tas) for most patients [2,3]. Research is 
moving ahead at a staggering speed and, consequently, the therapeutic arsenal is growing. Oral targeted treatments approved and available worldwide are: ibrutinib, the first generation of Bruton Tirosine Kinase inhibitors (BTKi); idelalisib, the first generation of phosphatidyl-inositol 3-kinase inhibitors (PI3Ki); and venetoclax (BCL-2 inhibitor). The European Medicine Agency (EMA) has just approved acalabrutinib, a second class BTKi. The second class PI3Ki, duvelisib is also available in some countries. Other second class BTKi (zanubrutinib), PI3Ki (umbralisib) or new reversible, non-covalent BTKi (pirtobrutinib, ARQ 531) are under investigation and will hopefully be available soon [4-18]. Therefore, the identification of prognostic and predictive biomarkers is relevant, not only for patient counseling but also for planning follow-up or selecting treatment at a time where a shift towards personalized medicine is taking place. Table S1 summarizes the names and principal characteristics of clinical trials with TAs and CIT in CLL mentioned throughout this review.

The difference between the terms prognostic and predictive biomarker has been previously addressed in depth $[19,20]$. In brief, prognostic biomarkers separate groups of patients with different outcomes regardless of treatment. On the contrary, a predictive biomarker provides information about the possible benefit of a specific treatment and can be used in the clinical decision-making process [21]. Many of the most powerful prognostic and predictive biomarkers were identified in the CIT era [22-28] but the validity of most of them has been evaluated also with oral Tas [6,11,12,29-31].

Although individual factors can be a very important prognostic tool, reality is more complex, as each patient may harbor several biomarkers with different prognostic value. To overcome this issue, prognostic scores have been developed integrating biomarkers into models. The Rai and Binet systems, proposed almost half a century ago, were the pioneers and, despite their limitations, they are still in force today [32,33]. Since then, various prognostic models and nomograms were proposed that can be applied at different moments during the course of the disease. The most established today is the CLL-International Prognostic Index (CLL-IPI), which has demonstrated its ability to predict overall survival (OS), time to first therapy (TTFT) and progression-free survival (PFS) in the CIT setting [34,35]. It has also shown to predict TTFT in early-stage CLL [36] and community-based cohorts of patients [37,38]. However, its utility to predict PFS and even OS in patients treated with Tas is limited [39]. Thus, other models have recently emerged to evaluate prognosis in this setting [40,41].

Herein, we discuss data evaluating the usefulness of prognostic and predictive biomarkers for patients treated with Tas. We also focus on novel prognostic models and the value of conventional models for patients treated with Tas.

\section{Prognostic Biomarkers: All That Glitters Is Not Gold}

Over the last 50 years, plenty of biomarkers with ability to predict CLL evolution were identified. The most relevant, classified by categories, are illustrated in Figure 1.

Even though they emerged in the era of CIT, most are valid today, since they are capable to predict time to first treatment (TTFT), which is not influenced by the choice of therapy [22-25,42-65]. The mutational status of immunoglobulin heavy chain variable region (IGHV) gene, cytogenetic abnormalities detected by FISH, CD49d expression and TP53 mutations are the biomarkers that have been consolidated as the most powerful ones and are supported by the best scientific evidence $[50,66]$. Others such as ZAP-70 and CD-38 have lost their strength, although their prognostic value is unquestionable. These flow cytometry biomarkers may be useful if IGHV mutation status is not available, as they act as surrogate markers. Among B-cell receptor biomarkers, a selective usage of IGHV genes in CLL has been described, with an overuse of certain genes. Some of these gene usages have been associated with clinical outcome such as VH1-69, VH3-21 (bad outcome) or VH 4-34 (good outcome) [67-70]. In addition, almost a third of CLL patients express stereotyped B cell receptor immunoglobulins (BcR IG). Some of these subsets also harbor prognostic value highlighting subsets \#1, \#2, \#8 (bad prognosis) and \#4 (good prognosis) [63,71]. Recently, a 
single point mutation in IGLV3-21 (R110-mutated IGLV3-21) has been studied, identifying an aggressive biological subtype of CLL [72].

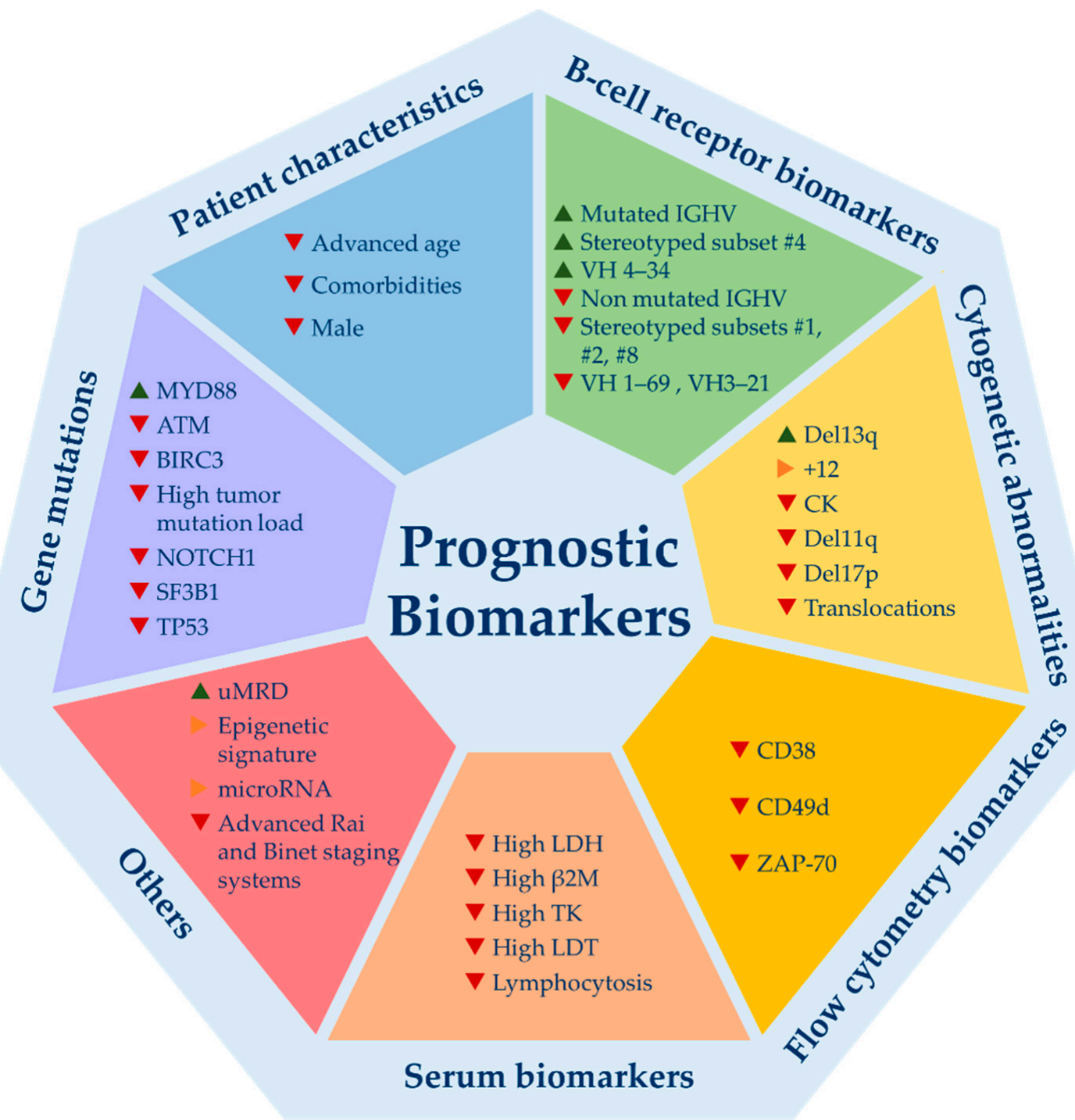

Figure 1. Relevant prognostic biomarkers for chronic lymphocytic leukemia. Del13q = 13q deletion; $+12=$ trisomy $12 ; \mathrm{CK}$ = complex karyotype; del11 $\mathrm{q}=11 \mathrm{q}$ deletion; del17 $\mathrm{p}=17 \mathrm{p}$ deletion; $\mathrm{LDH}=$ lactate dehydrogenase levels; $\beta 2 \mathrm{M}=$ beta-2microglobulin levels; TK = thymidine kinase; LDT = lymphocyte doubling time; $\mathrm{uMRD}=$ undetectable minimal residual disease. $\Delta$ indicates good prognosis; $\downarrow$ indicates good and bad prognosis or intermediate prognosis; $\nabla$ indicates poor prognosis.

Recurrent gene mutations identified by next generation whole exome or whole genome sequencing carry important prognostic information [61,73,74]. However, its implementation in routine practice has not been fully recommended to date, with the exception of TP53 mutation [1]. A great variety of mutations have been identified, but only a few occur in more than $\sim 5 \%$ of the patients. Among them stand out NOTCH1, SF3B1, ATM, BIRC3, POT1 and MYD88. All but MYD88 have been associated with adverse outcome and other poor prognostic biomarkers [75]. Some patient-related and tumor-load variables such as age, comorbidities, beta-2-microglobulin levels (B2M), lymphocytosis or lymphocyte doubling time (LDT) are available in virtually all patients and remain valid in predicting TTFT [76,77]. Novel markers such as complex karyotype (CK), stereotyped subsets, micro-RNAs or epigenetic subsets need more evidence to be used in the routine setting. Finally, minimal residual disease (MRD) is one of the strongest predictors of PFS and OS in CLL patients treated with CIT [78]. Indeed, undetectable MRD (uMRD) is considered a 
surrogate marker for PFS in the context of clinical trials. Regarding targeted treatments, BTKi or PI3Ki obtain very long PFS despite their low rates of complete responses (CR) and uMRD. Therefore, $\mathrm{uMRD}$ is not a valid prognostic biomarker for patients treated with BTK or PI3K inhibitors [5,6,11-13]. Conversely, venetoclax-based regimens induce high rates of uMRD enabling a fixed-duration treatment which has established UMRD as a therapeutic goal for these combinations. Moreover, the prognostic value of achieving uMRD with venetoclax has been demonstrated, not only in the relapsed/refractory $(R / R)$ setting but also as a frontline treatment (Murano and CLL14 phase 3 trials) [10,31]. Combos of novel agents (TA) between them +/ - anti-CD20 monoclonal antibodies or, less frequently, with CIT is what immediate future holds. Preliminary results of trials using these combinations are impressive with the highest rates of uMRD ever seen $(>50-70 \%)$, which might turn $\mathrm{uMRD}$ as the most powerful biomarker to predict prognosis in CLL patients that require treatment [79-83]. In fact, it could be used to guide treatment decisions in the near future by helping to decide when to stop or intensify therapy. Nevertheless, questions such as how to proceed with MRD results after a fixed duration schedule (stop, continue or change treatment) remain open. In summary, despite this large amount of biomarkers, not all have been externally and prospectively validated and, furthermore, few are valuable for clinical decision-making.

\section{Predictive Biomarkers in the Targeted Therapy Era: Something Old, Something New, Something Borrowed and Something Blue}

Predictive biomarkers allow anticipating the response to a specific treatment. In fact, they constitute the cornerstone on which therapeutic algorithms are based. As the therapeutic armamentarium expands, the need to identify and validate predictive biomarkers is reinforced with the aim of offering the treatment that best suits each patient. Nowadays, American and European guidelines base their treatment algorithms on age and comorbidities, IGHV mutation status and the presence of TP53 mutation or del(17p) [2,3]. In summary, Tas are recommended in all settings as first line treatment, highlighting their preferred use over CIT for patients with TP53 abnormalities (TP53 mutations or del(17p)) or unmutated IGHV status. The exception where CIT might be appropriated, at the same level as Tas, is for young patients without TP53 abnormalities and mutated IGHV status. This is justified by the results of the ECOG-ACRIN E1912 clinical trial that compared ibrutinib-rituximab versus fludarabine-cyclophosphamide-rituximab (FCR) in patients 70 years of age or younger. The combination of ibrutinib-rituximab resulted to be superior to FCR in terms of PFS and OS. This benefit was observed for all subgroups with the exception of IGHV-mutated patients, in which both treatments achieved similar results and a long follow-up is required to determine the best option for this population. [8]. Given the change in the therapeutic algorithm that has occurred, some predictive factors will lose their value, especially if CIT disappears from the treatment scenario. Others are emerging to help tailoring treatment decisions that involve Tas and combinations. In this section, we summarize the current situation of factors with predictive value with special focus on BTKi (ibrutinib, acalabrutinib) and BCL-2 inhibitors (venetoclax).

\subsection{Something Old: Invalid Biomarkers for Current Treatment Algorithms That Were Important Previously and Might Reappear \\ 11q Deletion}

Twenty years ago, Döhner et al. demonstrated the prognostic value of certain cytogenetic abnormalities detected by FISH. The $11 \mathrm{q}$ deletion $(\operatorname{del}(11 \mathrm{q})$ ) is detected in around $20 \%$ of the patients who require first line treatment and is associated with unfavorable outcome $[42,84]$. Initial studies with CIT pointed out that the addition of anti-CD20 could overcome the bad prognosis that del(11q) entailed, suggesting that this abnormality could be considered a predictive biomarker for increased response to FCR or obinutuzumabchlorambucil (O-Chl) [85,86]. Later, as antiCD-20 was added universally to chemotherapy protocols, its predictive utility disappeared. More than $80 \%$ of the patients with del(11q) have an unmutated-IGHV (U-CLL) pattern, another poor outcome marker for patients 
treated with CIT. In the low proportion of patients with mutated-IGHV (M-CLL) and $\operatorname{del}(11 q)$, the prognostic role that $\operatorname{del}(11 q)$ adds is controversial. The CLL-8 trial found that this subgroup of patients (M-CLL and del(11q)) had an excellent outcome, similar to other M-CLL [87]. In contrast, results from an Italian multicenter retrospective study with 404 patients, showed that M-CLL patients without del(11q) had a better outcome than those who carried this deletion [88].

The prognostic value of $\mathrm{del}(11 \mathrm{q})$ in patients treated with ibrutinib has recently been addressed in a pooled analysis that compiled results from three phase 3 clinical trials that recruited 620 patients. In this study, a longer PFS and a possible OS benefit (not significant) was observed for patients with del(11q) who were treated with ibrutinib compared to those without this cytogenetic alteration [89]. Indeed, the authors suggested that del(11q) could be used as a predictive biomarker for better outcomes in patients receiving this drug. Anyway, this observation needs further validation and studies with preclinical models harboring this alteration, which will help to understand 11q-related effects on treatment response [90]. Direct comparison with other treatment options such as venetoclax or acalabrutinib combinations should be also explored. In fact, acalabrutinib and venetoclax also overcome the bad prognosis of $\operatorname{del}(11 \mathrm{q})$, as reported in the subgroup analysis of major phase 3 trials of both molecules [11,12,30,31].

\subsection{Something New: Novel Biomarkers for the Tas Treatments \\ 3.2.1. Resistance Mutations to BTK Inhibitors}

Despite the excellent results provided by ibrutinib, a few patients do not respond (primary resistance) and others relapse during treatment (acquired resistance). A responsible mutation can be identified in around $60-80 \%$ of the patients with acquired resistance [91-93]. These mutations occur at the binding site of ibrutinib to BTK, usually at position C481S. Less frequent, activating mutations in the PLCG2 pathway might be detected. In some patients, both types coexist [91,92,94]. Interestingly, BTK and PLCG2 mutations were not observed in patients without previous exposure to ibrutinib and usually appear between the second and fourth year under treatment [91]. Not only that, some studies were able to detect these mutations in samples around 9-15 months before relapse happened [95]. Nevertheless, it is unknown whether all patients with treatment mutations will relapse, and how long it will take. In conclusion, acquired mutations could represent biomarkers of resistance to ibrutinib. The advantage of their early detection and the possible switch to other treatments is still to be determined. Recent reports have shown that mechanisms of resistance to acalabrutinib are similar than to ibrutinib, which is not surprising as acalabrutinib uses the same position (C481S) to bind to BTK [96]. For readers interested in this topic, comprehensive reviews have been published and are available in the references cited below [97-101].

\subsubsection{BCL-2 Mutations}

Resistance to venetoclax is a more complex process in which different independent molecular mechanisms are involved [102]. However, a mutation at the G101V location in BCL-2 has been found but in around $50 \%$ of the patients in a small study that analyzed samples from 15 patients relapsing on venetoclax. This mutation behaves similar to BTK C481S on three aspects: it affects the venetoclax affinity to BCL-2, it has been detected only after venetoclax exposure and it can be observed several months prior to clinical relapse ( 25) $[103,104]$. The same authors published in another small study that a median of 3 other BCL-2 mutations (different than G101V) may appear in most of R/R patients (91\%) [105]. Hence, BCL-2 mutations might also act as biomarkers for venetoclax resistance. 


\subsection{Something Borrowed: Biomarkers That Retain Predictive Value on Current Treatment Algorithms}

\subsubsection{TP53 Abnormalities}

TP53 abnormalities (TP53a) (del(17p), TP53 mutations or both) result in a loss of p53 activity, leading to an impaired regulation of DNA repair mechanisms and resistance to chemotherapy. These abnormalities are infrequent among untreated patients (5-12\%) but increase significantly during disease evolution, especially after treatment or at the time of transformation (40-60\%). CIT offers no benefit to patients with TP53a that obtain very short PFS and OS regardless of the combination used [106]. Fortunately, Tas have significantly improved clinical outcomes in patients with TP53a, since they act independently of the p53 protein, which has placed them as the gold standard approach for this subset of patients. However, none of them have completely overcome the bad prognosis that TP53a carries. In the $R / R$ setting, ibrutinib trials, with a prolonged follow-up time, showed that patients with TP53a had a shorter PFS than patients without these abnormalities (41 months vs. 57 months at RESONATE trial) [6]. Conversely, the results from a phase 2 trial (NCT01500733) that included 34 previously untreated patients with TP53a showed a median PFS and OS of $61 \%$ and $79 \%$ respectively with a follow-up time of 6.5 years [107]. These results need to be interpreted cautiously due to the low proportion of patients included in the study and the lack of randomization. In addition, the median age of the patients was 62.5 year old, suggesting that the study included a younger and highly selected population and therefore not representative. Acalabrutinib behaves very similar to ibrutinib for patients with TP53a not only in the first line but also in the R/R setting, but studies with this compound need a longer follow-up to see the long-term effect [11,12]. Venetoclax-based regimens have also demonstrated to be very active on patients with TP53a. Nevertheless, the 4-year update of the MURANO trial showed a higher proportion of patients with detectable MRD after end of trial and a trend to a lower PFS on patients carrying del(17p) without statistical significance after multivariable adjustment. In addition, the 5-year update recently communicated at the American Society of Hematology meeting confirmed that the four patients with $\operatorname{del}(17 \mathrm{p})$ that achieved uMRD after end of treatment progressed [108]. Similarly, patients with TP53a from the CLL-14 trial had a shorter PFS (2-year PFS around 70\%) than those with intact TP53. A slightly higher 2-year PFS (75-80\%) has been reported on ibrutinib trials what has led some experts to recommend ibrutinib over venetoclax in TP53a [2,10]. Shortly, ongoing trials comparing both molecules will establish the preferential option for these patients. Meanwhile, we can establish that TP53a have a predictive value for a shorter duration of response to Tas especially in the context of relapse and poor response to CIT.

\subsubsection{IGHV Mutational Status}

IGHV mutational status is a robust prognostic biomarker in CLL. M-CLL patients exhibit a more benign course of the disease with a prolonged TTFT and OS, in contrast to UCLL $[23,24,60,66,109]$. Furthermore, it is also considered a valuable predictive biomarker for CIT response, especially for the FCR combination. Three independent studies demonstrated that FCR has probably the potential to "cure" a subset of patients with M-CLL. In these three studies, the PFS and OS curves reached a plateau with times comparable to agematched healthy population $[87,88,110]$. However, the predictive value of IGHV mutation status has changed with the advent of Tas. These drugs achieve similar PFS and OS rates regardless of IGHV mutation status [6,10-12,31,111]. In addition, studies comparing Tas vs. CIT on previously untreated elderly/unfit patients (ALLIANCE A041202, CLL-14) support the preferential use of Tas regardless of IGHV mutation status $[7,10]$. On the other hand, the E1912 trial could possibly help to answer one of the burning questions today [8]: Will young M-CLL patients benefit more from FCR or Tas? If the answer is Tas, IGHV mutation could lose its predictive value, since it will no longer be used as a premise for first line treatment decisions. If the answer is FCR, IGHV might remain as a predictive biomarker favoring FCR for most of the M-CLL patients. 


\subsection{Something Blue: Biomarkers with Potential Predictive Value Not Fully Validated \\ 3.4.1. Complex Karyotype}

The frequency of complex karyotype (CK) varies between 10\% (treatment-naïve) and $40 \%(\mathrm{R} / \mathrm{R})$ and is back in the spotlight again thanks to CpG-stimulation techniques [112]. Recent studies have pointed out that CK might also be identified using genomic arrays. The detection of $\geq 5$ copy number alterations by this technique identified a subgroup of patients with independent adverse prognosis in a multicenter retrospective study that included more than 2000 patients [113].

In spite of the controversies that surround this biomarker, it seems clear that, altogether, it confers a dismal prognosis to CLL, and some guidelines advocate for its incorporation in clinical practice [3]. In the first place, there is an urgent need to generate an international standardized consensus on the exact definition of CK and how to count and interpret chromosomal abnormalities. In general, CK in CLL is defined by the presence of $\geq 3$ abnormalities and high risk CK by the presence of $\geq 5$ aberrations. However, not all cases with more than three abnormalities behave the same way. For instance, the association of trisomy $12(+12)$, trisomy 19 and other trisomies provides good prognosis, while unbalanced translocations appear to carry a worse outcome than balanced translocations [114,115].

Secondly, CK was designated as a poor prognostic factor and a predictive biomarker for poor response to CIT based on large retrospective cohort studies $[28,77,116,117]$. This bad outcome has not been verified in the context of prospective randomized trials. The results of the only two trials in which CK independently predicted OS and PFS for patients treated with either FCR or chlorambucil (Chl) are illustrated in Table S2. As shown in the table, the methodology used in both studies was suboptimal.

Third and last, Tas might overcome the poor prognosis that CK entails, but this is another topic of debate. Table 1 summarizes the studies that have assessed the impact of $\mathrm{CK}$ in patients receiving Tas. As shown, the results are discordant.

Table 1. Impact of complex karyotype on clinical outcome for patients treated with ibrutinib, acalabrutinib and venetoclax.

\begin{tabular}{|c|c|c|c|c|c|c|c|c|}
\hline Drug & Impact of CK & Study Type & Study & N (\% CK) & Population & Prognostic Impact of CK & Others & Ref. \\
\hline \multirow{6}{*}{ } & \multirow{4}{*}{$\begin{array}{l}\text { CK does not } \\
\text { impact } \\
\text { outcome }\end{array}$} & Phase 3 CT & RESONATE & $39 / 153(25 \%)$ & $\mathrm{R} / \mathrm{R}$ & $\begin{array}{c}\text { No impact on PFS (40 vs. } \\
44 \text { months, NS) }\end{array}$ & & {$[6]$} \\
\hline & & Phase 3 CT & $\begin{array}{l}\text { ALLIANCE } \\
\text { A041202 }\end{array}$ & $99 / 333(29 \%)$ & $\mathrm{TN}$ & No impact on PFS & & [7] \\
\hline & & $\begin{array}{l}\text { Pooled } \\
\text { analysis }\end{array}$ & $\begin{array}{l}\text { PCYC-1102 } \\
\text { PCYC1103 }\end{array}$ & $41 / 132(31 \%)$ & $\mathrm{TN} \& \mathrm{R} / \mathrm{R}$ & $\begin{array}{c}\text { No impact on PFS and OS } \\
\text { in MA }\end{array}$ & & [118] \\
\hline & & $\begin{array}{l}\text { Pooled } \\
\text { analysis }\end{array}$ & $\begin{array}{l}\text { RESONATE } \\
\text { RESONATE } 2 \\
\text { HELIOS }\end{array}$ & $41 / 338(12.1 \%)$ & $\mathrm{TN} \& \mathrm{R} / \mathrm{R}$ & No impact on PFS or OS & $\begin{array}{l}\text { Excluded } \\
\text { del(17p) }\end{array}$ & [89] \\
\hline & \multirow{2}{*}{$\begin{array}{l}\text { CK aggravates } \\
\text { outcome }\end{array}$} & Retrospective & & $21 / 56(37.5 \%)$ & $\mathrm{R} / \mathrm{R}$ & $\begin{array}{l}\text { Independently associated } \\
\text { with shorter PFS and OS }\end{array}$ & $17 / 21 \operatorname{del}(17 p)$ & [119] \\
\hline & & $\begin{array}{l}\text { Pooled } \\
\text { analysis }\end{array}$ & $\begin{array}{l}\text { PCYC-1102 } \\
\text { PCYC-1109 } \\
\text { OSU11 } \\
\text { RESONATE }\end{array}$ & $172 / 295(58 \%)$ & $\mathrm{R} / \mathrm{R}(8 \mathrm{TN})$ & $\begin{array}{c}\text { Associated with disease } \\
\text { progression or } \\
\text { transformation }\end{array}$ & & [91] \\
\hline \multirow{3}{*}{ 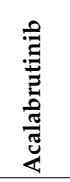 } & \multirow{3}{*}{$\begin{array}{c}\text { CK does not } \\
\text { impact } \\
\text { outcome } \\
\text { CK aggravates } \\
\text { outcome }\end{array}$} & Phase 3 CT & ASCEND & $50 / 154(32 \%)$ & $\mathrm{R} / \mathrm{R}$ & $\begin{array}{l}\text { PFS benefit for acala arm } \\
\text { on subgroup analysis }\end{array}$ & $\begin{array}{l}16 \text { m median } \\
\text { follow up }\end{array}$ & [11] \\
\hline & & Phase 3 CT & ELEVATE TN & $60 / 358(16.7 \%)$ & $\mathrm{TN}$ & $\begin{array}{l}\text { PFS benefit for acala arms } \\
\text { on subgroup analysis }\end{array}$ & $\begin{array}{l}28 \text { m median } \\
\text { follow up }\end{array}$ & {$[12]$} \\
\hline & & Phase $1 / 2 \mathrm{CT}$ & & $20 / 57(35 \%)$ & $\mathrm{R} / \mathrm{R}$ & Shorter PFS (33m vs. NR) & & [120] \\
\hline \multirow{4}{*}{ 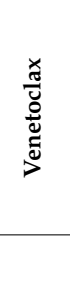 } & \multirow{2}{*}{$\begin{array}{l}\text { CK does not } \\
\text { impact } \\
\text { outcome }\end{array}$} & Phase 3 CT & CLL-14 & $30 / 200(17 \%)$ & $\mathrm{TN}$ & $\begin{array}{c}\text { No impact on PFS or OS } \\
\text { (not reached in CK and } \\
\text { non-CK) }\end{array}$ & & [121] \\
\hline & & Retrospective & Cohort & $52 / 130(26.8 \%)$ & $\mathrm{R} / \mathrm{R}(2 \mathrm{TN})$ & No impact on PFS & $\begin{array}{l}7 \text { m median } \\
\text { follow up }\end{array}$ & [122] \\
\hline & $\begin{array}{l}\text { CK aggravates } \\
\text { outcome }\end{array}$ & $\begin{array}{l}\text { Pooled } \\
\text { analysis }\end{array}$ & $\begin{array}{l}\text { M12-175 } \\
\text { M13-365 } \\
\text { M13-982 }\end{array}$ & $16 / 38(46 \%)$ & $\mathrm{R} / \mathrm{R}$ & $\begin{array}{l}\text { CK independently } \\
\text { associated with PFS }\end{array}$ & $\begin{array}{l}23 \text { m median } \\
\text { follow up }\end{array}$ & [123] \\
\hline & & Phase 3 CT & MURANO & $\begin{array}{l}94 / 288 \\
(36.3 \%)\end{array}$ & $\mathrm{R} / \mathrm{R}$ & $\begin{array}{l}\text { Shorter PFS and uMRD } \\
\text { for CK }\end{array}$ & $\begin{array}{c}4 \text { year } \\
\text { follow up }\end{array}$ & {$[31]$} \\
\hline
\end{tabular}

$\mathrm{N}=$ number of patients; $\mathrm{CK}=$ complex karyotype; $\mathrm{REF}=$ reference; $\mathrm{CT}=$ clinical trial; $\mathrm{R} / \mathrm{R}=$ relapsed $/$ refractory; $\mathrm{PFS}=$ progression free survival; $\mathrm{TN}=$ treatment-naïve; $\mathrm{OS}=$ overall survival; $\mathrm{MA}=$ multivariate analysis; $\operatorname{del}(17 \mathrm{p})=17 \mathrm{p}$ deletion; $\mathrm{m}=\mathrm{months} ; \mathrm{uMRD}=\mathrm{undetectable}$ minimal residual disease; acala = acalabrutinib. 
Starting with ibrutinib, overall, treatment naïve patients that receive this drug appear to get prolonged responses irrespectively of cytogenetics [7]. On the other hand, if CK appears as a consequence of treatment, the situation changes. Even though the RESONATE trial (R/R), with a follow up of 6 years, could not identify CK as a predictive biomarker [6], other studies have linked CK to relapse, transformation and even a resistance mechanism $[91,119]$. In this setting CK usually comes with other dismal factors such as del(17p), del(18p) or acquired mutations, maybe acting as a confounding factor. Not surprisingly, the same conclusions can be extrapolated from acalabrutinib studies, albeit with a shorter follow-up (Table 1) [11,12,124]. With regard to venetoclax, a recent report from the CLL-14 highlights that venetoclax-obinutuzumab is able to overcome the deleterious effect of CK, in line with a previous study from real life [121,122]. Both studies need a prolonged follow-up to confirm these outcomes. In contrast, evidence from the MURANO trial (R/R) and early studies with venetoclax, showed the opposite [123] (Table 1).

Interestingly, two different studies (retrospective single center analysis with ibrutinib and the MURANO trial) have recently demonstrated that increasing karyotype complexity to $\geq 5$ abnormalities predicts inferior survival for patients treated with TAs, similarly to what happens with CIT $[31,125]$. This reinforces the need for harmonization and standardization of CK definitions.

Finally, although the widespread use of idelalisib has been limited by toxicity, it is worth mentioning that this molecule might vanquish the bad prognosis of $\mathrm{CK}$ even for $R / R$ patients, although with little evidence [126]. To sum up, the predictive value of $C K$ in the era of Tas is not clear. From our point of view, patients with this biomarker should be preferentially treated with Tas, turning this marker into a predictor of better response to Tas than CIT.

\subsubsection{NOTCH1 Mutations}

NOTCH1 mutations are the most common recurrent mutations, seen in about $10 \%$ of CLL-patients, with increasing frequency as the disease progresses. This biomarker has been proposed as a mild negative prognostic factor, based on evidence from retrospective studies and clinical trials [73,127-131]. Indeed, patients with NOTCH1 mutations constitute a heterogeneous subgroup of patients in which other factors are also important. For example the association of NOTCH1 mutation to +12 seems to overshadow the clinical outcome of patients with +12 [132,133]. In addition, clonal and subclonal NOTCH1 mutations predicted inferior TTFT while only clonal mutations predicted inferior OS in a cohort of patients treated with CIT [134]. Mutations of the NOTCH1 appear to be a predictive biomarker of response to anti-CD20 treatments. The CLL8 trial showed lack of benefit from adding rituximab to conventional CT [84]. Furthermore, in trials using ofatumumab as a comparator arm, patients with wild-type NOTCH1 performed better than those with the mutation [29]. In contrast, patients with NOTCH1 mutations treated with obinutuzumab had a better outcome than patients treated with rituximab [135]. However, these observations need further validation to be incorporated into routine practice. In general, the PFS and OS of patients treated with Tas do not appear to be influenced by the presence or absence of NOTCH1 mutations $[29,136]$. Therefore, NOTCH1 is proposed as a biomarker that predicts inferior response to rituximab or ofatumumab, but at the moment it has no impact "by itself" in patients treated with Tas.

\section{Prognostic Models. Different Models for Different Moments: Do Not Compare Apples with Oranges}

After the enormous advance in deciphering the biological landscape of CLL, which has been accompanied by a "treatment-revolution" and a significant improve on survival, prognostic models have not evolved at the same speed [137]. Rai [33] and Binet [32] clinical staging systems, available for almost 50 years, have the merit of being in force today. Their major limitation is that none of the models is accurate enough to predict clinical outcome at the individual level and discriminate patients with early-stage disease that progress in a short period of time. With the aim of improving the accuracy of these models, many scoring 
systems have emerged, integrating biological and clinical variables. Most of the models were initially developed to predict OS in the CIT era. Others were designed to predict TTFT and are not influenced by treatment decisions. A recent meta-analysis published by the Cochrane Library has analyzed this topic in depth. They identified 52 prognostic models, but only 12 were externally validated ( 5 for TTFT; 6 for OS and 1 for PFS). Thus, prognostic models validated in the CIT period will not be the subject of this review. In this section, we review current evidence about prognostic models based on their applicability to predict TTFT and for patients treated with Tas [138].

\subsection{Apples: Scoring Systems That Predict Time to First Treatment}

The percentage of CLL patients diagnosed at early stages (Binet A, Rai 0) is now very high $(\sim 80 \%)$ due to the generalization of routine blood tests in asymptomatic people [139]. Prognostic models developed to evaluate TTFT help to counsel patients and their families, plan surveillance and identify high-risk candidates that may benefit from early intervention in the context of clinical trials. For this purpose, many scoring systems were published $[36,109,140-144]$ but most of them have not been validated in independent cohorts and thus, are not transferred to clinical practice [138]. Table 2 summarizes the most relevant. Two of them deserve special mention. First, the recently published IPS-E that has been validated in nine external cohorts and only requires two clinical variables and one molecular (IGHV mutation status) for its implementation. Authors of this work concluded that the simplicity of this score might facilitate its translation to the clinic, although this requires knowledge of the IGHV mutation status since diagnosis [109]. Second, the innovative European Research Initiative on CLL (ERIC) "tailored approach" score that separates M-CLL and U-CLL and elaborates two different scores for each subset of patients. In this case, translation to the clinic will be more difficult, since it includes biomarkers not widely available such as SF3B1 mutation or stereotyped subsets [143].

Table 2. Selection of prognostic models validated to predict time to first treatment.

\begin{tabular}{|c|c|c|c|c|c|}
\hline Model & Population & Stage & Biomarkers & Risk Groups & Validation \\
\hline $\begin{array}{c}\text { MDAC } \\
2011[141]\end{array}$ & $\begin{array}{l}\text { Retrospective } \\
\text { single-center cohort }\end{array}$ & All & $\begin{array}{c}\text { IGHV ms } \\
\text { Diameter of largest palpable LN } \\
\text { FISH (11q/17p Vs none) } \\
\text { N involved LN sites } \\
\text { LDH } \\
\text { IGHV-LDH interaction }\end{array}$ & Nomogram & 1 external \\
\hline $\begin{array}{c}\text { O-CLL1 } \\
2016[142]\end{array}$ & $\begin{array}{l}\text { Prospective } \\
\text { multicenter cohort }\end{array}$ & Binet A & $\begin{array}{l}\text { IGHV ms } \\
\text { Rai stage } \\
\text { ALC } \\
\text { B2M }\end{array}$ & 3 & 3 external \\
\hline $\begin{array}{l}\text { CLL-IPI } \\
2016[145]\end{array}$ & $\begin{array}{l}8 \text { Ph3 multicenter } \\
\text { clinical trials }\end{array}$ & All & $\begin{array}{c}\text { IGHV ms } \\
\text { TP53 status } \\
\text { B2M } \\
\text { Clinical stage } \\
\text { Age }\end{array}$ & 3 & 9 external \\
\hline $\begin{array}{l}\text { Barcelona-Brno } \\
2017 \text { [140] }\end{array}$ & $\begin{array}{c}\text { Retrospective } \\
\text { single-center cohort }\end{array}$ & All (83\% Binet A) & $\begin{array}{c}\text { IGHV ms } \\
\operatorname{del}(17 p) / \operatorname{del}(11 q)\end{array}$ & 3 & 7 external \\
\hline $\begin{array}{l}\text { Tailored approach } \\
2019 \text { [143] }\end{array}$ & $\begin{array}{c}\text { Retrospective } \\
\text { multicenter cohort }\end{array}$ & Binet A & $\begin{array}{c}\text { M-CLL: TP53 abn; +12; subset \#2 } \\
\text { U-CLL: TP53 abn; del(11q); } \\
\text { gender }\end{array}$ & $\begin{array}{l}2 \\
3\end{array}$ & 2 external \\
\hline $\begin{array}{c}\text { IPS-E } \\
2020[109]\end{array}$ & $\begin{array}{l}\text { Multicenter } \\
\text { retrospective cohort }\end{array}$ & Binet $\mathrm{A}$ & $\begin{array}{c}\text { IGHV ms } \\
\text { ALC }>15 \times 10^{9} / \mathrm{L} \\
\text { Palpable LN }\end{array}$ & 3 & 9 external \\
\hline $\begin{array}{l}\text { CLL-1 PM } \\
2020[144]\end{array}$ & Ph 3 clinical trial & Binet A & $\begin{array}{l}\text { IGHV ms } \\
\text { del }(11 \mathrm{q}) \\
\text { del }(17 \mathrm{p}) \\
\text { B2M } \\
\text { LDT }<12 \mathrm{~m} \\
\text { Age }\end{array}$ & 4 & No \\
\hline
\end{tabular}

IGHV ms = IGHV mutation status; LN = lymph node; $\mathrm{N}$ = number; ALC = absolute lymphocyte count; B2M = beta-2-microglobuline; +12 = trisomy 12; TP53abn = TP53 abnormalities; $\mathrm{m}$ = months; LDT = lymphocyte doubling time. 
Our group recently published data comparing the accuracy of five scores (IPS-E, CLL-01, CLL-IPI, Barcelona-Brno and tailored approach) in a multicentric cohort of Binet A patients. We found that the most accurate score in predicting TTFT was IPS-E with a low concordance between the different models. In addition, none of the models was able to predict the clinical course of the disease with absolute accuracy, as one quarter of the patients could have been assigned to an incorrect risk group with any of the PIs used, underscoring that models cannot totally replace clinical expertise [146].

\subsection{Oranges: Scoring Systems That Predict OS for Patients Treated with New Targeted Agents}

As previously stated, a recent meta-analysis revealed that despite the high amount of published prognostic models, only six had been externally validated for OS and all of them were tested for patients treated with CIT. The popular CLL-IPI was the model with the best discrimination power [138]. The CLL-IPI scores the highest values to TP53 abnormalities (4 points), B2M and U-CLL ( 2 points each). Given that Tas improve the poor prognosis provided by TP53a and U-CLL, it is not surprising that CLL-IPI decreases its accuracy for patients treated with these drugs. A retrospective cohort analysis of 326 frontlineibrutinib-treated patients could analyze the CLL-IPI on 79 and found that it did not predict 12 month PFS [147]. The prognostic utility of the CLL-IPI has also been addressed in a cohort of R/R patients treated with idelalisib-rituximab in the context of phase 3 trials [148]. Most patients ( $85 \%)$ were assigned to the high or very high risk subgroups and the discriminatory value of the CLL-IPI was less robust (C-statistic 0.6 ) than in its original publication and subsequent validation studies and meta-analyses (C-statistic 0.72 ). Thus, the authors proposed a modified version of the CLL-IPI, assigning only 1 point to each adverse factor and modifying the cut-off of clinical stage. An external validation study showed that this modified version of the CLL-IPI failed to provide prognostic information in a cohort of patients from real life treated with ibrutinib [149]. Molica et al. performed a systematic review that analyzed published studies that had applied the CLL-IPI to patients treated with CIT or Tas. They grouped data from the two studies previously commented and, not surprisingly, concluded that the utility of the CLL-IPI remains uncertain for patients treated with Tas [39].

Therefore, the "old" scores do not seem to be valid for patients receiving Tas. To cover this gap, novel prognostic models built with data from individuals treated with Tas have emerged. Table 3 compares and summarizes the principal characteristics of these models.

Table 3. Description of the published prognostic scores developed to predict outcomes for patients treated with targeted agents.

\begin{tabular}{|c|c|c|c|c|}
\hline Characteristics & BALL [40] & NIH (Ahn et al.) [41] & Simplified PI [150] & $\mathrm{SRS}_{\mathrm{I}}[151]$ \\
\hline $\mathrm{N}$ & 2475 & 720 & 346 & 541 \\
\hline Study & $\begin{array}{c}\text { Retrospective multicenter } \\
\text { pool cohort from randomized } \\
\text { trials }\end{array}$ & $\begin{array}{l}\text { Retrospective pooled cohort } \\
\text { from randomized trials }\end{array}$ & $\begin{array}{l}\text { Retrospective multicenter } \\
\text { cohort from academic } \\
\text { medical centers }\end{array}$ & $\begin{array}{l}\text { Retrospective multicenter } \\
\text { working group, real } \\
\text { life patients }\end{array}$ \\
\hline Treatment & $\begin{array}{c}\text { Ibrutinib } \\
\text { Idelalisib } \\
\text { Venetoclax } \\
\text { CIT }\end{array}$ & Ibrutinib & Ibrutinib & Ibrutinib \\
\hline Population & $R / R$ & $\mathrm{TN}$ and $\mathrm{R} / \mathrm{R}$ & $\mathrm{TN}$ and $\mathrm{R} / \mathrm{R}$ & $\mathrm{R} / \mathrm{R}$ \\
\hline Validation cohorts & $\begin{array}{l}1 \text { internal } \\
4 \text { external }\end{array}$ & $\begin{array}{l}1 \text { internal } \\
1 \text { external }\end{array}$ & No & $\begin{array}{l}1 \text { internal } \\
1 \text { external }\end{array}$ \\
\hline Scores & $\begin{array}{c}\text { B2M } \geq 5 \rightarrow 1 \mathrm{p} \\
\mathrm{LDH}>\mathrm{ULN} \rightarrow 1 \mathrm{p} \\
\mathrm{Hb}<11 \mathrm{~F} / 12 \mathrm{M} \rightarrow 1 \mathrm{p} \\
\text { TILT }<24 \mathrm{~m} \rightarrow 1 \mathrm{p}\end{array}$ & $\begin{array}{c}\mathrm{B} 2 \mathrm{M} \geq 5 \rightarrow 1 \mathrm{p} \\
\mathrm{LDH}>250 \mathrm{U} / \mathrm{L} \rightarrow 1 \mathrm{p} \\
T P 53 \mathrm{ab} \rightarrow 1 \mathrm{p} \\
\text { Prior treatment } \rightarrow 1 \mathrm{p}\end{array}$ & $\begin{array}{l}\text { Age } \geq 70 \rightarrow 1 \mathrm{p} \\
\mathrm{R} / \mathrm{R} \rightarrow 1 \mathrm{p} \\
\mathrm{ECOG} \geq 1 \rightarrow 1 \mathrm{p}\end{array}$ & $\begin{array}{c}\mathrm{B} 2 \mathrm{M} \geq 5 \rightarrow 1 \mathrm{p} \\
\mathrm{LDH}>\mathrm{ULT} \rightarrow 1 \mathrm{p} \\
\mathrm{Hb}<11 \mathrm{~F} / 12 \mathrm{M} \rightarrow 2 \mathrm{p}\end{array}$ \\
\hline Groups & $\begin{array}{c}\text { Low }(0-1) \\
\text { Intermediate }(2-3) \\
\text { High }(4)\end{array}$ & $\begin{array}{c}\text { Low }(0-1) \\
\text { Intermediate (2) } \\
\text { High (3-4) }\end{array}$ & $\begin{array}{c}\text { Low }(0-1) \\
\text { Intermediate (2) }\end{array}$ & $\begin{array}{l}\text { Low }(0) \\
\text { Intermediate (1-3) }\end{array}$ \\
\hline Prediction & OS & PFS and OS & PFS and OS & OS \\
\hline Accuracy & $\mathrm{CS}=0.79(\mathrm{OS})$ & $\mathrm{CS}=0.69(\mathrm{PFS})$ & $\begin{aligned} \text { AUC } & =0.6(\mathrm{PFS}) \\
\mathrm{AUC} & =0.66(\mathrm{OS})\end{aligned}$ & $\mathrm{CS}=0.71(\mathrm{OS})$ \\
\hline Other & & $\begin{array}{l}\text { BTK and PLG2 mutations } \\
\text { detected more frequently in } \\
\text { the high risk group }\end{array}$ & & \\
\hline
\end{tabular}

$\mathrm{NIH}=$ National Institutes of Health; Simplified PI = simplified prognostic index; $\mathrm{SRS}_{\mathrm{I}}=$ survival risk score ibrutinib; $\mathrm{N}=$ number; $\mathrm{R} / \mathrm{R}=$ relapsed / refractory; $\mathrm{TN}$ = treatment naïve; $\mathrm{B} 2 \mathrm{M}=$ beta2microglobulin; $\mathrm{ULN}=$ upper normal limit; $\mathrm{Hb}=$ hemoglobin; $\mathrm{F}=$ female; $\mathrm{M}=$ male; TP53ab = TP53abnormalities; TILT = time from initiation of last therapy; ECOG = Eastern Cooperative Oncology Group; $\mathrm{CS}=\mathrm{C}$-statistic AUC $=$ area under the curve. 
Briefly, the BALL and the NIH (Ahn et al.) scores were generated with clinical trial data, while the simplified PI and the SRS were generated with real life data. The NIH and the "simplified score" are suitable for the frontline and R/R settings. However, the "simplified score" has not been validated in other cohorts. The BALL score included patients with all type of Tas and CIT, while the other scores were applied to ibrutinibtreated-patients. The NIH score was able to assign most patients that generated secondary BTK and PLCG2 acquired mutations to the high risk group. Very recently, the BALL and the NIH (Ahn et al.) models were validated in another external study and at the same time compared to the CLL-IPI model. The discriminatory ability of the two scores was better than that of CLL-IPI. The BALL score had the best discriminatory capacity with respect to OS and the NIH score with the PFS prediction. The NIH score was the only model that provided a good prediction of both PFS and OS [152].

Interestingly, all these models used parameters related to bone marrow reserve and tumor burden, widely available worldwide, which a priori suggest that its introduction into clinical practice should be easy and straightforward. The only genetic data included in one score is TP53 mutation, which agrees with what was previously stated about the loss of the prognostic and predictive value of many other genetic factors such as IGHV mutation status or del(11q) with the arrival of Tas. However, further work is needed to explore the relevance of including novel biomarkers such as complex karyotype, uMRD and recurrent or acquired mutations in the context of new scores. Recently, a promising dynamic score named Continuous Individualized Risk Index (CIRI) has been published and applied to patients with diffuse large B cell lymphoma, CLL and breast cancer. It has been developed with the aim of predicting a personalized probability of PFS and OS over time, considering the response to treatment as a feature. In CLL (CIRI-CLL), it has been built with variables such as the CLL-IPI, MRD or the choice of therapy. Furthermore, CIRI-CLL has demonstrated to provide superior outcome prediction to current prognostic indices (CLL-IPI) with a better C-statistic value in patients treated with CIT [153].

Other challenges include determining which is the most accurate score and whether in real life they can help the clinicians select high-risk patients who will benefit from novel treatments/combinations. Probably, new technology such as machine learning will be crucial to solve all these challenges. Machine learning is able to evaluate in a non-linearity and a more complex way data from different variables. In addition, artificial technology algorithms can deal with missing data form retrospective studies form the real-world setting to improve the precision of the models [154]. Nevertheless, clinical expertise and medical judgement should be complemented and not be replaced by models [20].

\section{Conclusions}

Predicting the outcome of CLL is an important and dynamic field of research that evolves in parallel with biological and therapeutic advances. From the patient's perspective, it provides information that can help with personal planning. It also guides clinicians toward the best therapeutic option and is an important step in personalized medicine. Novel targeted agents have changed treatment algorithms in CLL and, consequently, the role of predictive biomarkers has been questioned. Herein, we provided a critical view of the currently most controversial issues regarding the value of prognostic and predictive biomarkers as well as prognostic models for patients with CLL treated with Tas. In summary, prognostic factors from the CIT era remain valid for predicting time to first treatment, being the most important FISH abnormalities, IGHV mutational status, TP53 abnormalities and CD49d. Achieving uMRD after treatment is an important survival biomarker for venetoclax-based regimens but not for BTKi or PI3Ki. The few predictive biomarkers validated in the CIT era do not behave the same way right now. For instance, if an old patient is going to be treated with Tas, IGHV mutational status will no longer be a predictive biomarker for treatment election. On the other hand, the classic del(11q) might be a biomarker of better response to Tas. TP53 abnormalities seem to ameliorate but not mitigate the poor outcome that they provide when patients receive Tas instead of 
CIT. CK may be the most controversial biomarker in the setting of Tas providing better outcome when it is detected in treatment-naïve than in the R/R patients. Acquired BTK and BCL-2 mutations are good candidates to be used as biomarkers for treatment failure. The predictive value of other biomarkers like NOTCH1 mutations needs further studies. Concerning prognostic models, the accuracy of the classic systems such as the CLL-IPI has been reduced for patients undergoing Tas. Thus, new models such as the BALL and the $\mathrm{NIH}$ (Ahn et al.) have been proposed to predict outcome for patients receiving novel agents. For patients with early stage CLL, other scores have also been published, highlighting the IPS-E prognostic model, easily applicable and widely validated. However, all the prognostic models need to be complemented with clinical expertise.

In conclusion, despite that we are moving in the right direction, there is still scope for improvement in CLL prognostication. Some biomarkers are already extinct but surely new ones will appear and others will evolve to be incorporated in the changing landscape of CLL.

Supplementary Materials: The following are available online at https:/ / www.mdpi.com/article/ 10.3390/cancers13081782/s1, Table S1: Characteristics of main clinical trials that involve chemoimmunotherapy and oral targeted agents, Table S2: Clinical trials in which the prognostic value of complex karyotype has been evaluated for patients treated with chemoimmunotherapy.

Author Contributions: Writing—original draft preparation, concept and writing, I.G.-G.-y.-M.; writing-review and editing, C.M.-N., A.-E.R.-V., M.Q.-Á., M.H.-S., C.P.-C., V.R.-A. and J.-Á.H.$R$. All authors have read and agreed to the published version of the manuscript.

Funding: This research was funded by grants from the Spanish Fondo de Investigaciones Sanitarias PI15/01471, PI18/01500, Instituto de Salud Carlos III (ISCIII), European Regional Development Fund (ERDF) "Una manera de hacer Europa", "Consejería de Educación, Junta de Castilla y León" (SA271P18, SA118P20), "Proyectos de Investigación del SACYL", Spain GRS 1847/A/18, GRS1653/A17,“Fundación Memoria Don Samuel Solórzano Barruso” (FS/23-2018, FS/33-2020), by grants (RD12/0036/0069) from Red Temática de Investigación Cooperativa en Cáncer (RTICC), Centro de Investigación Biomédica en Red de Cáncer (CIBERONC CB16/12/00233) and SYNtherapy "Synthetic Lethality for Personalized Therapy-based Stratification In Acute Leukemia" (ERAPERMED2018-275); ISCIII (AC18/00093). M.Q.Á. was fully supported by an "Ayuda predoctoral de la Junta de Castilla y León" by the Fondo Social Europeo (JCYL-EDU/529/2017 PhD scholarship) and is now a recipient of FEHH ("Fundación Española de Hematología y Hemoterapia"); C.P.C. was supported by an "Ayuda predoctoral en Oncología" (Asociación Española contra el Cáncer) and is a recipient of a PFIS grant (FI19/00191) from Instituto de Salud Carlos III (ISCiii); M.H.S. was supported by a grant from FEHH/Janssen ("Sociedad Española de Hematología y Hemoterapia") and now holds a Sara Borrell post-doctoral contract (CD19/00222) from the ISCiii. PFIS grant and Sara Borrell postdoctoral contract are co-founded by Fondo Social Europeo (FSE) “El Fondo Social Europeo invierte en tu futuro"; A.E.R.V. is supported with a research grant by FEHH ("Fundación Española de Hematología y Hemoterapia").

Institutional Review Board Statement: Not applicable.

Informed Consent Statement: Not applicable.

Conflicts of Interest: The authors declare no conflict of interest.

\section{References}

1. Hallek, M.; Cheson, B.D.; Catovsky, D.; Caligaris-Cappio, F.; Dighiero, G.; Döhner, H.; Hillmen, P.; Keating, M.; Montserrat, E.; Chiorazzi, N.; et al. iwCLL guidelines for diagnosis, indications for treatment, response assessment, and supportive management of CLL. Blood 2018, 131, 2745-2760. [CrossRef]

2. Eichhorst, B.; Robak, T.; Montserrat, E.; Ghia, P.; Niemann, C.U.; Kater, A.P.; Gregor, M.; Cymbalista, F.; Buske, C.; Hillmen, P.; et al. Chronic lymphocytic leukaemia: ESMO Clinical Practice Guidelines for diagnosis, treatment and follow-up. Ann. Oncol. 2021, 32, 23-33. [CrossRef]

3. NCCN. NCCN Clinical Practice Guidelines in Oncology: Chronic Lymphocytic Leukemia/Small Lymphocytic Lymphoma Version 2.2021. Available online: https://www.nccn.org/professionals/physician_gls/pdf/cll.pdf (accessed on 9 February 2021). 
4. $\quad$ Byrd, J.C.; Furman, R.R.; Coutre, S.E.; Flinn, I.W.; Burger, J.A.; Blum, K.; Sharman, J.P.; Wierda, W.; Zhao, W.; Heerema, N.A.; et al. Ibrutinib Treatment for First-Line and Relapsed/Refractory Chronic Lymphocytic Leukemia: Final Analysis of the Pivotal Phase Ib/II PCYC-1102 Study. Clin. Cancer Res. 2020, 26, 3918-3927. [CrossRef]

5. Burger, J.A.; Barr, P.M.; Robak, T.; Owen, C.; Ghia, P.; Tedeschi, A.; Bairey, O.; Hillmen, P.; Coutre, S.E.; Devereux, S.; et al. Long-term efficacy and safety of first-line ibrutinib treatment for patients with CLL/SLL: 5 years of follow-up from the phase 3 RESONATE-2 study. Leukemia 2020, 34, 787-798. [CrossRef]

6. Munir, T.; Brown, J.R.; O’Brien, S.; Barrientos, J.C.; Barr, P.M.; Reddy, N.M.; Coutre, S.; Tam, C.S.; Mulligan, S.P.; Jaeger, U.; et al. Final analysis from RESONATE: Up to six years of follow-up on ibrutinib in patients with previously treated chronic lymphocytic leukemia or small lymphocytic lymphoma. Am. J. Hematol. 2019, 94, 1353-1363. [CrossRef] [PubMed]

7. Woyach, J.A.; Ruppert, A.S.; Heerema, N.A.; Zhao, W.; Booth, A.M.; Ding, W.; Bartlett, N.L.; Brander, D.M.; Barr, P.M.; Rogers, K.A.; et al. Ibrutinib Regimens versus Chemoimmunotherapy in Older Patients with Untreated CLL. N. Engl. J. Med. 2018, 379, 2517-2528. [CrossRef] [PubMed]

8. Shanafelt, T.D.; Wang, X.V.; Kay, N.E.; Hanson, C.A.; O’Brien, S.; Barrientos, J.; Jelinek, D.F.; Braggio, E.; Leis, J.F.; Zhang, C.C.; et al. Ibrutinib-Rituximab or Chemoimmunotherapy for Chronic Lymphocytic Leukemia. N. Engl. J. Med. 2019, 381, 432-443. [CrossRef] [PubMed]

9. Kater, A.P.; Seymour, J.F.; Hillmen, P.; Eichhorst, B.; Langerak, A.W.; Owen, C.; Verdugo, M.; Wu, J.; Punnoose, E.A.; Jiang, Y.; et al. Fixed Duration of Venetoclax-Rituximab in Relapsed/Refractory Chronic Lymphocytic Leukemia Eradicates Minimal Residual Disease and Prolongs Survival: Post-Treatment Follow-Up of the MURANO Phase III Study. J. Clin. Oncol. 2019, 37, $269-277$. [CrossRef]

10. Al-Sawaf, O.; Zhang, C.; Tandon, M.; Sinha, A.; Fink, A.-M.; Robrecht, S.; Samoylova, O.; Liberati, A.M.; Pinilla-Ibarz, J.; Opat, S.; et al. Venetoclax plus obinutuzumab versus chlorambucil plus obinutuzumab for previously untreated chronic lymphocytic leukaemia (CLL14): Follow-up results from a multicentre, open-label, randomised, phase 3 trial. Lancet Oncol. 2020, 21, 1188-1200. [CrossRef]

11. Ghia, P.; Pluta, A.; Wach, M.; Lysak, D.; Kozak, T.; Simkovic, M.; Kaplan, P.; Kraychok, I.; Illes, A.; de la Serna, J.; et al. ASCEND: Phase III, Randomized Trial of Acalabrutinib Versus Idelalisib Plus Rituximab or Bendamustine Plus Rituximab in Relapsed or Refractory Chronic Lymphocytic Leukemia. J. Clin. Oncol. 2020, 38, 2849-2861. [CrossRef]

12. Sharman, J.P.; Egyed, M.; Jurczak, W.; Skarbnik, A.; Pagel, J.M.; Flinn, I.W.; Kamdar, M.; Munir, T.; Walewska, R.; Corbett, G.; et al. Calabrutinib with or without obinutuzumab versus chlorambucil and obinutuzumab for treatment-naive chronic lymphocytic leukaemia (ELEVATE-TN): A randomised, controlled, phase 3 trial. Lancet 2020, 395, 1278-1291. [CrossRef]

13. Sharman, J.P.; Coutre, S.E.; Furman, R.R.; Cheson, B.D.; Pagel, J.M.; Hillmen, P.; Barrientos, J.C.; Zelenetz, A.D.; Kipps, T.J.; Flinn, I.W.; et al. Final results of a randomized, phase iii study of rituximab with or without idelalisib followed by open-label idelalisib in patients with relapsed chronic lymphocytic leukemia. J. Clin. Oncol. 2019, 37, 1391-1402. [CrossRef]

14. Flinn, I.W.; Hillmen, P.; Montillo, M.; Nagy, Z.; Illés, Á.; Etienne, G.; Delgado, J.; Kuss, B.J.; Tam, C.S.; Gasztonyi, Z.; et al. The phase 3 DUO trial: Duvelisib vs ofatumumab in relapsed and refractory CLL/SLL. Blood 2018, 132, 2446-2455. [CrossRef]

15. Tam, C.S.; Trotman, J.; Opat, S.; Burger, J.A.; Cull, G.; Gottlieb, D.; Harrup, R.; Johnston, P.B.; Marlton, P.; Munoz, J.; et al. Phase 1 study of the selective BTK inhibitor zanubrutinib in B-cell malignancies and safety and efficacy evaluation in CLL. Blood 2019, 134, 851-859. [CrossRef] [PubMed]

16. Danilov, A.V.; Herbaux, C.; Walter, H.S.; Hillmen, P.; Rule, S.A.; Kio, E.A.; Karlin, L.; Dyer, M.J.S.; Mitra, S.S.; Yi, P.C.; et al. Phase $\mathrm{Ib}$ Study of Tirabrutinib in Combination with Idelalisib or Entospletinib in Previously Treated Chronic Lymphocytic Leukemia. Clin. Cancer Res. 2020, 26, 2810-2818. [CrossRef]

17. Mato, A.R.; Ghosh, N.; Schuster, S.J.; Lamanna, N.; Pagel, J.M.; Flinn, I.W.; Barrientos, J.; Rai, K.R.; Reeves, J.A.; Cheson, B.D.; et al. Phase 2 Study of the Safety and Efficacy of Umbralisib in Patients with CLL Who are Intolerant to BTK or PI3K $\delta$ Inhibitor Therapy. Blood 2020. [CrossRef] [PubMed]

18. Iskierka-Jażdżewska, E.; Robak, T. Investigational treatments for chronic lymphocytic leukemia: A focus on phase 1 and 2 clinical trials. Expert Opin. Investig. Drugs 2020, 1-14. [CrossRef]

19. Rossi, D.; Gerber, B.; Stüssi, G. Predictive and prognostic biomarkers in the era of new targeted therapies for chronic lymphocytic leukemia. Leuk. Lymphoma 2017, 58, 1548-1560. [CrossRef] [PubMed]

20. Montserrat, E.; Gale, R.P. Predicting the outcome of patients with chronic lymphocytic leukemia: Progress and uncertainty. Cancer 2019, 125, 3699-3705. [CrossRef]

21. Califf, R.M. Biomarker definitions and their applications. Exp. Biol. Med. 2018, 243, 213-221. [CrossRef] [PubMed]

22. Döhner, H.; Stilgenbauer, S.; Benner, A.; Leupolt, E.; Kröber, A.; Bullinger, L.; Döhner, K.; Bentz, M.; Lichter, P. Genomic Aberrations and Survival in Chronic Lymphocytic Leukemia. N. Engl. J. Med. 2000, 343, 1910-1916. [CrossRef]

23. Damle, R.N.; Wasil, T.; Fais, F.; Ghiotto, F.; Valetto, A.; Allen, S.L.; Buchbinder, A.; Budman, D.; Dittmar, K.; Kolitz, J.; et al. Ig V Gene Mutation Status and CD38 Expression as Novel Prognostic Indicators in Chronic Lymphocytic Leukemia. Blood 1999, 94 , 1840-1847. [CrossRef] [PubMed]

24. Hamblin, T.J.; Davis, Z.; Gardiner, A.; Oscier, D.G.; Stevenson, F.K. Unmutated Ig V(H) genes are associated with a more aggressive form of chronic lymphocytic leukemia. Blood 1999, 94, 1848-1854. [CrossRef] [PubMed] 
25. Crespo, M.; Bosch, F.; Villamor, N.; Bellosillo, B.; Colomer, D.; Rozman, M.; Marcé, S.; López-Guillermo, A.; Campo, E.; Montserrat, E. ZAP-70 Expression as a Surrogate for Immunoglobulin-Variable-Region Mutations in Chronic Lymphocytic Leukemia. N. Engl. J. Med. 2003, 348, 1764-1775. [CrossRef] [PubMed]

26. Baumann, T.; Delgado, J.; Santacruz, R.; Martínez-Trillos, A.; Rozman, M.; Aymerich, M.; López, C.; Costa, D.; Carrió, A.; Villamor, $\mathrm{N}$; ; et al. CD49d (ITGA4) expression is a predictor of time to first treatment in patients with chronic lymphocytic leukaemia and mutatedIGHVstatus. Br. J. Haematol. 2016, 172, 48-55. [CrossRef]

27. Ghia, P.; Guida, G.; Stella, S.; Gottardi, D.; Geuna, M.; Strola, G.; Scielzo, C.; Caligaris-Cappio, F. The pattern of CD38 expression defines a distinct subset of chronic lymphocytic leukemia (CLL) patients at risk of disease progression. Blood 2003, 101, 1262-1269. [CrossRef]

28. Herling, C.D.; Klaumünzer, M.; Rocha, C.K.; Altmüller, J.; Thiele, H.; Bahlo, J.; Kluth, S.; Crispatzu, G.; Herling, M.; Schiller, J.; et al. Complex karyotypes and KRAS and POT1 mutations impact outcome in CLL after chlorambucil-based chemotherapy or chemoimmunotherapy. Blood 2016, 128, 395-404. [CrossRef] [PubMed]

29. Brown, J.R.; Hillmen, P.; O’Brien, S.; Barrientos, J.C.; Reddy, N.M.; Coutre, S.E.; Tam, C.S.; Mulligan, S.P.; Jaeger, U.; Barr, P.M.; et al. Extended follow-up and impact of high-risk prognostic factors from the phase 3 RESONATE study in patients with previously treated CLL/SLL. Leukemia 2018, 32, 83-91. [CrossRef]

30. Tausch, E.; Schneider, C.; Robrecht, S.; Zhang, C.; Dolnik, A.; Bloehdorn, J.; Bahlo, J.; Al-Sawaf, O.; Ritgen, M.; Fink, A.-M.; et al. Prognostic and predictive impact of genetic markers in patients with CLL treated with obinutuzumab and venetoclax. Blood 2020. [CrossRef]

31. Kater, A.P.; Wu, J.Q.; Kipps, T.; Eichhorst, B.; Hillmen, P.; D’Rozario, J.; Assouline, S.; Owen, C.; Robak, T.; de la Serna, J.; et al. Venetoclax Plus Rituximab in Relapsed Chronic Lymphocytic Leukemia: 4-Year Results and Evaluation of Impact of Genomic Complexity and Gene Mutations from the MURANO Phase III Study. J. Clin. Oncol. 2020, 38, 4042-4054. [CrossRef]

32. Binet, J.L.; Auquier, A.; Dighiero, G.; Chastang, C.; Piguet, H.; Goasguen, J.; Vaugier, G.; Potron, G.; Colona, P.; Oberling, F.; et al. A new prognostic classification of chronic lymphocytic leukemia derived from a multivariate survival analysis. Cancer 1981, 48 , 198-206. [CrossRef]

33. Rai, K.R.; Sawitsky, A.; Cronkite, E.P.; Chanana, A.D.; Levy, R.N.; Pasternack, B.S. Clinical staging of chronic lymphocytic leukemia. Blood 1975, 46, 219-234. [CrossRef] [PubMed]

34. International CLL-IPI Working Group. An international prognostic index for patients with chronic lymphocytic leukaemia (CLL-IPI): A meta-analysis of individual patient data. Lancet Oncol. 2016, 17, 779-790. [CrossRef]

35. Gentile, M.; Shanafelt, T.D.; Mauro, F.R.; Reda, G.; Rossi, D.; Laurenti, L.; Del Principe, M.I.; Cutrona, G.; Angeletti, I.; Coscia, M.; et al. Predictive value of the CLL-IPI in CLL patients receiving chemo-immunotherapy as first-line treatment. Eur. J. Haematol. 2018. [CrossRef] [PubMed]

36. Molica, S.; Shanafelt, T.D.; Giannarelli, D.; Gentile, M.; Mirabelli, R.; Cutrona, G.; Levato, L.; Di Renzo, N.; Di Raimondo, F.; Musolino, C.; et al. The chronic lymphocytic leukemia international prognostic index predicts time to first treatment in early CLL: Independent validation in a prospective cohort of early stage patients. Am. J. Hematol. 2016, 91, 1090-1095. [CrossRef] [PubMed]

37. Da Cunha-Bang, C.; Christiansen, I.; Niemann, C.U. The CLL-IPI applied in a population-based cohort. Blood 2016, 128, 2181-2183. [CrossRef]

38. Muñoz-Novas, C.; Poza-Santaella, M.; Marín, I.G.-G.Y., I; Hernández-Sánchez, M.; Rodríguez-Vicente, A.-E.; Infante, M.-S.; Heras, C.; Foncillas, M.-Á.; Marín, K.; Hernández-Rivas, J.-M.; et al. The International Prognostic Index for Patients with Chronic Lymphocytic Leukemia has the Higher Value in Predicting Overall Outcome Compared with the Barcelona-Brno Biomarkers Only Prognostic Model and the MD Anderson Cancer Center Prognostic Index. Biomed. Res. Int. 2018, 2018, 9506979. [CrossRef] [PubMed]

39. Molica, S.; Giannarelli, D.; Mirabelli, R.; Levato, L.; Shanafelt, T.D. Chronic lymphocytic leukemia international prognostic index (CLL-IPI) in patients receiving chemoimmuno or targeted therapy: A systematic review and meta-analysis. Ann. Hematol. 2018, 97, 2005-2008. [CrossRef]

40. Soumerai, J.D.; Ni, A.; Darif, M.; Londhe, A.; Xing, G.; Mun, Y.; Kay, N.E.; Shanafelt, T.D.; Rabe, K.G.; Byrd, J.C.; et al. Prognostic risk score for patients with relapsed or refractory chronic lymphocytic leukaemia treated with targeted therapies or chemoimmunotherapy: A retrospective, pooled cohort study with external validations. Lancet Haematol. 2019, 6, e366-e374. [CrossRef]

41. Ahn, I.E.; Tian, X.; Ipe, D.; Cheng, M.; Albitar, M.; Tsao, L.C.; Zhang, L.; Ma, W.; Herman, S.E.M.; Gaglione, E.M.; et al. Prediction of Outcome in Patients with Chronic Lymphocytic Leukemia Treated with Ibrutinib: Development and Validation of a Four-Factor Prognostic Model. J. Clin. Oncol. 2020, JCO2000979. [CrossRef]

42. Van Dyke, D.L.; Werner, L.; Rassenti, L.Z.; Neuberg, D.; Ghia, E.; Heerema, N.A.; Dal Cin, P.; Dell Aquila, M.; Sreekantaiah, C.; Greaves, A.W.; et al. The Dohner fluorescence in situ hybridization prognostic classification of chronic lymphocytic leukaemia (CLL): The CLL Research Consortium experience. Br. J. Haematol. 2016, 173, 105-113. [CrossRef]

43. Autore, F.; Strati, P.; Innocenti, I.; Corrente, F.; Trentin, L.; Cortelezzi, A.; Visco, C.; Coscia, M.; Cuneo, A.; Gozzetti, A.; et al. Elevated Lactate Dehydrogenase has Prognostic Relevance in Treatment-Naïve Patients Affected by Chronic Lymphocytic Leukemia with Trisomy 12. Cancers 2019, 11, 896. [CrossRef] 
44. Delgado, J.; Pratt, G.; Phillips, N.; Briones, J.; Fegan, C.; Nomdedeu, J.; Pepper, C.; Aventin, A.; Ayats, R.; Brunet, S.; et al. Beta2-microglobulin is a better predictor of treatment-free survival in patients with chronic lymphocytic leukaemia if adjusted according to glomerular filtration rate. Br. J. Haematol. 2009, 145, 801-805. [CrossRef]

45. Hallek, M.; Langenmayer, I.; Nerl, C.; Knauf, W.; Dietzfelbinger, H.; Adorf, D.; Ostwald, M.; Busch, R.; Kuhn-Hallek, I.; Thiel, E.; et al. Elevated serum thymidine kinase levels identify a subgroup at high risk of disease progression in early, nonsmoldering chronic lymphocytic leukemia. Blood 1999, 93, 1732-1737.

46. Montserrat, E.; Sanchez-Bisono, J.; Viñolas, N.; Rozman, C. Lymphocyte doubling time in chronic lymphocytic leukaemia: Analysis of its prognostic significance. Br. J. Haematol. 1986, 62, 567-575. [CrossRef]

47. Tadmor, T.; Braester, A.; Najib, D.; Aviv, A.; Herishanu, Y.; Yuklea, M.; Shvidel, L.; Rahimi-Levene, N.; Ruchlemer, R.; Arad, A.; et al. A new risk model to predict time to first treatment in chronic lymphocytic leukemia based on heavy chain immunoparesis and summated free light chain. Eur. J. Haematol. 2019, 103, 335-341. [CrossRef] [PubMed]

48. Catovsky, D.; Fooks, J.; Richards, S. Prognostic factors in chronic lymphocytic leukaemia: The importance of age, sex and response to treatment in survival. Br. J. Haematol. 1989, 72, 141-149. [CrossRef]

49. Strugov, V.; Stadnik, E.; Virts, Y.; Andreeva, T.; Zaritskey, A. Impact of age and comorbidities on the efficacy of FC and FCR regimens in chronic lymphocytic leukemia. Ann. Hematol. 2018, 97, 2153-2161. [CrossRef]

50. Bulian, P.; Shanafelt, T.D.; Fegan, C.; Zucchetto, A.; Cro, L.; Nückel, H.; Baldini, L.; Kurtova, A.V.; Ferrajoli, A.; Burger, J.A.; et al. CD49d is the Strongest Flow Cytometry-Based Predictor of Overall Survival in Chronic Lymphocytic Leukemia. J. Clin. Oncol. 2014, 32, 897-904. [CrossRef] [PubMed]

51. Ibrahem, L.; Elderiny, W.E.; Elhelw, L.; Ismail, M. CD49d and CD26 are independent prognostic markers for disease progression in patients with chronic lymphocytic leukemia. Blood Cells Mol. Dis. 2015, 55, 154-160. [CrossRef] [PubMed]

52. Hernández, J.A.; Rodríguez, A.E.; González, M.; Benito, R.; Fontanillo, C.; Sandoval, V.; Romero, M.; Martín-Núñez, G.; de Coca, A.G.; Fisac, R.; et al. A high number of losses in 13q14 chromosome band is associated with a worse outcome and biological differences in patients with B-cell chronic lymphoid leukemia. Haematologica 2009, 94, 364-371. [CrossRef] [PubMed]

53. Cavazzini, F.; Hernandez, J.A.; Gozzetti, A.; Rossi, A.R.; de Angeli, C.; Tiseo, R.; Bardi, A.; Tammiso, E.; Crupi, R.; Lenoci, M.P.; et al. Chromosome 14q32 translocations involving the immunoglobulin heavy chain locus in chronic lymphocytic leukaemia identify a disease subset with poor prognosis. Br. J. Haematol. 2008, 142, 529-537. [CrossRef]

54. Hernández, J.Á.; Hernández-Sánchez, M.; Rodríguez-Vicente, A.E.; Grossmann, V.; Collado, R.; Heras, C.; Puiggros, A.; Martín, A.Á.; Puig, N.; Benito, R.; et al. A Low Frequency of Losses in 11q Chromosome is Associated with Better Outcome and Lower Rate of Genomic Mutations in Patients with Chronic Lymphocytic Leukemia. PLoS ONE 2015, 10, e0143073. [CrossRef]

55. Marín, I.G.-G.Y.; Hernández-Sánchez, M.; Rodríguez-Vicente, A.-E.; Sanzo, C.; Aventín, A.; Puiggros, A.; Collado, R.; Heras, C.; Muñoz, C.; Delgado, J.; et al. A high proportion of cells carrying trisomy 12 is associated with a worse outcome in patients with chronic lymphocytic leukemia. Hematol. Oncol. 2016, 34, 84-92. [CrossRef]

56. Delgado, J.; Espinet, B.; Oliveira, A.C.; Abrisqueta, P.; de la Serna, J.; Collado, R.; Loscertales, J.; Lopez, M.; Hernandez-Rivas, J.A.; Ferra, C.; et al. Chronic lymphocytic leukaemia with 17p deletion: A retrospective analysis of prognostic factors and therapy results. Br. J. Haematol. 2012, 157, 67-74. [CrossRef]

57. Heerema, N.A.; Muthusamy, N.; Zhao, Q.; Ruppert, A.S.; Breidenbach, H.; Andritsos, L.A.; Grever, M.R.; Maddocks, K.J.; Woyach, J.; Awan, F.; et al. Prognostic significance of translocations in the presence of mutated IGHV and of cytogenetic complexity at diagnosis of chronic lymphocytic leukemia. Haematologica 2020. [CrossRef]

58. Pérez-Carretero, C.; Hernández-Sánchez, M.; González, T.; Quijada-Álamo, M.; Martín-Izquierdo, M.; Hernández-Sánchez, J.-M.; Vidal, M.-J.; de Coca, A.G.; Aguilar, C.; Vargas-Pabón, M.; et al. Chronic lymphocytic leukemia patients with IGH translocations are characterized by a distinct genetic landscape with prognostic implications. Int. J. Cancer 2020, 147, 2780-2792. [CrossRef] [PubMed]

59. Baliakas, P.; Hadzidimitriou, A.; Sutton, L.-A.; Minga, E.; Agathangelidis, A.; Nichelatti, M.; Tsanousa, A.; Scarfò, L.; Davis, Z.; Yan, X.-J.; et al. Clinical effect of stereotyped B-cell receptor immunoglobulins in chronic lymphocytic leukaemia: A retrospective multicentre study. Lancet Haematol. 2014, 1, e74-e84. [CrossRef]

60. Marín, I.G.-G.Y., I; Hernández, J.A.; Martín, A.; Alcoceba, M.; Sarasquete, M.E.; Rodríguez-Vicente, A.; Heras, C.; de Las Heras, N.; Fisac, R.; García de Coca, A.; et al. Mutation Status and Immunoglobulin Gene Rearrangements in Patients from Northwest and Central Region of Spain with Chronic Lymphocytic Leukemia. Biomed. Res. Int. 2014, 2014, 257517. [CrossRef]

61. Landau, D.A.; Tausch, E.; Taylor-Weiner, A.N.; Stewart, C.; Reiter, J.G.; Bahlo, J.; Kluth, S.; Bozic, I.; Lawrence, M.; Böttcher, S.; et al. Mutations driving CLL and their evolution in progression and relapse. Nature 2015, 526, 525-530. [CrossRef]

62. Puente, X.S.; Pinyol, M.; Quesada, V.; Conde, L.; Ordóñez, G.R.; Villamor, N.; Escaramis, G.; Jares, P.; Beà, S.; González-Díaz, M.; et al. Whole-genome sequencing identifies recurrent mutations in chronic lymphocytic leukaemia. Nature 2011, 475, 101-105. [CrossRef]

63. Jaramillo, S.; Agathangelidis, A.; Schneider, C.; Bahlo, J.; Robrecht, S.; Tausch, E.; Bloehdorn, J.; Hoechstetter, M.; Fischer, K.; Eichhorst, B.; et al. Prognostic impact of prevalent chronic lymphocytic leukemia stereotyped subsets: Analysis within prospective clinical trials of the German CLL Study Group (GCLLSG). Haematologica 2020, 105, 2598-2607. [CrossRef] [PubMed]

64. Queirós, A.C.; Villamor, N.; Clot, G.; Martinez-Trillos, A.; Kulis, M.; Navarro, A.; Penas, E.M.M.; Jayne, S.; Majid, A.; Richter, J.; et al. A B-cell epigenetic signature defines three biologic subgroups of chronic lymphocytic. Leukemia 2015, 29, 598-605. [CrossRef] 
65. Baliakas, P.; Puiggros, A.; Xochelli, A.; Sutton, L.-A.; Nguyen-Khac, F.; Gardiner, A.; Plevova, K.; Minga, E.; Hadzidimitriou, A.; Walewska, R.; et al. Additional trisomies amongst patients with chronic lymphocytic leukemia carrying trisomy 12: The accompanying chromosome makes a difference. Haematologica 2016, 101, e299-e302. [CrossRef]

66. Parikh, S.A.; Strati, P.; Tsang, M.; West, C.P.; Shanafelt, T.D. Should IGHV status and FISH testing be performed in all CLL patients at diagnosis? A systematic review and meta-analysis. Blood 2016, 127, 1752-1760. [CrossRef]

67. Thorsélius, M.; Kröber, A.; Murray, F.; Thunberg, U.; Tobin, G.; Bühler, A.; Kienle, D.; Albesiano, E.; Maffei, R.; Dao-Ung, L.-P.; et al. Strikingly homologous immunoglobulin gene rearrangements and poor outcome in VH3-21-using chronic lymphocytic leukemia patients independent of geographic origin and mutational status. Blood 2006, 107, 2889-2894. [CrossRef] [PubMed]

68. Ghia, P.; Stamatopoulos, K.; Belessi, C.; Moreno, C.; Stella, S.; Guida, G.; Michel, A.; Crespo, M.; Laoutaris, N.; Montserrat, E.; et al. Geographic patterns and pathogenetic implications of IGHV gene usage in chronic lymphocytic leukemia: The lesson of the IGHV3-21 gene. Blood 2005, 105, 1678-1685. [CrossRef]

69. Tobin, G.; Rosén, A.; Rosenquist, R. What is the current evidence for antigen involvement in the development of chronic lymphocytic leukemia? Hematol. Oncol. 2006, 24, 7-13. [CrossRef]

70. Xochelli, A.; Baliakas, P.; Kavakiotis, I.; Agathangelidis, A.; Sutton, L.-A.; Minga, E.; Ntoufa, S.; Tausch, E.; Yan, X.-J.; Shanafelt, T.; et al. Chronic Lymphocytic Leukemia with Mutated IGHV4-34 Receptors: Shared and Distinct Immunogenetic Features and Clinical Outcomes. Clin. Cancer Res. 2017, 23, 5292-5301. [CrossRef]

71. Agathangelidis, A.; Darzentas, N.; Hadzidimitriou, A.; Brochet, X.; Murray, F.; Yan, X.-J.; Davis, Z.; van Gastel-Mol, E.J.; Tresoldi, C.; Chu, C.C.; et al. Stereotyped B-cell receptors in one-third of chronic lymphocytic leukemia: A molecular classification with implications for targeted therapies. Blood 2012, 119, 4467-4475. [CrossRef]

72. Nadeu, F.; Royo, R.; Clot, G.; Duran-Ferrer, M.; Navarro, A.; Martin, S.; Lu, J.; Zenz, T.; Baumann, T.S.; Jares, P.; et al. IGLV3-21R110 identifies an aggressive biological subtype of chronic lymphocytic leukemia with intermediate epigenetics. Blood 2020. [CrossRef]

73. Puente, X.S.; Beà, S.; Valdés-Mas, R.; Villamor, N.; Gutiérrez-Abril, J.; Martín-Subero, J.I.; Munar, M.; Rubio-Pérez, C.; Jares, P.; Aymerich, M.; et al. Non-coding recurrent mutations in chronic lymphocytic leukaemia. Nature 2015, 526, 519-524. [CrossRef]

74. Landau, D.A.; Carter, S.L.; Stojanov, P.; McKenna, A.; Stevenson, K.; Lawrence, M.S.; Sougnez, C.; Stewart, C.; Sivachenko, A.; Wang, L.; et al. Evolution and Impact of Subclonal Mutations in Chronic Lymphocytic Leukemia. Cell 2013, 152, 714-726. [CrossRef]

75. Bosch, F.; Dalla-Favera, R. Chronic lymphocytic leukaemia: From genetics to treatment. Nat. Rev. Clin. Oncol. 2019, 16, 684-701. [CrossRef]

76. Yun, X.; Zhang, Y.; Wang, X. Recent progress of prognostic biomarkers and risk scoring systems in chronic lymphocytic leukemia. Biomark. Res. 2020, 8, 40. [CrossRef] [PubMed]

77. Rigolin, G.M.; Cavallari, M.; Quaglia, F.M.; Formigaro, L.; Lista, E.; Urso, A.; Guardalben, E.; Liberatore, C.; Faraci, D.; Saccenti, E.; et al. In CLL, comorbidities and the complex karyotype are associated with an inferior outcome independently of CLL-IPI. Blood 2017, 129, 3495-3498. [CrossRef]

78. Kovacs, G.; Robrecht, S.; Fink, A.M.; Bahlo, J.; Cramer, P.; von Tresckow, J.; Maurer, C.; Langerbeins, P.; Fingerle-Rowson, G.; Ritgen, M.; et al. Minimal Residual Disease Assessment Improves Prediction of Outcome in Patients With Chronic Lymphocytic Leukemia (CLL) Who Achieve Partial Response: Comprehensive Analysis of Two Phase III Studies of the German CLL Study Group. J. Clin. Oncol. 2016, 34, 3758-3765. [CrossRef]

79. Tam, C.S.; Siddiqi, T.; Allan, J.N.; Kipps, T.J.; Flinn, I.W.; Kuss, B.J.; Opat, S.; Barr, P.M.; Tedeschi, A.; Jacobs, R.; et al. Ibrutinib (Ibr) Plus Venetoclax (Ven) for First-Line Treatment of Chronic Lymphocytic Leukemia (CLL)/Small Lymphocytic Lymphoma (SLL): Results from the MRD Cohort of the Phase 2 CAPTIVATE Study. Blood 2019, 134, 35. [CrossRef]

80. Jain, N.; Keating, M.; Thompson, P.; Ferrajoli, A.; Burger, J.; Borthakur, G.; Takahashi, K.; Estrov, Z.; Fowler, N.; Kadia, T.; et al. Ibrutinib and Venetoclax for First-Line Treatment of CLL. N. Engl. J. Med. 2019, 380, 2095-2103. [CrossRef] [PubMed]

81. Lampson, B.L.; Tyekucheva, S.; Crombie, J.L.; Kim, A.I.; Merryman, R.W.; Lowney, J.; Montegaard, J.; Patterson, V.; Jacobson, C.A.; Jacobsen, E.D.; et al. Preliminary Safety and Efficacy Results from a Phase 2 Study of Acalabrutinib, Venetoclax and Obinutuzumab in Patients with Previously Untreated Chronic Lymphocytic Leukemia (CLL). Blood 2019, 134, 32. [CrossRef]

82. Munir, T.; Webster, N.; Boucher, R.; Dalal, S.; Brock, K.; Yates, F.J.; Sankhalpara, C.; MacDonald, D.; Fegan, C.; McCaig, A.; et al. Continued Long Term Responses to Ibrutinib + Venetoclax Treatment for Relapsed/Refractory CLL in the Blood Cancer UK TAP Clarity Trial. Blood 2020, 136, 17-18. [CrossRef]

83. Wierda, W.G.; Tam, C.; Allan, J.N.; Siddiqi, T.; Kipps, T.; Opat, S.; Tedeschi, A.; Badoux, X.C.; Kuss, B.J.; Jackson, B.; et al. Ibrutinib (Ibr) Plus Venetoclax (Ven) for First-Line Treatment of Chronic Lymphocytic Leukemia (CLL)/Small Lymphocytic Lymphoma (SLL): 1-Year Disease-Free Survival (DFS) Results from the MRD Cohort of the Phase 2 CAPTIVATE Study. Blood 2020, $136,16-17$. [CrossRef]

84. Stilgenbauer, S.; Schnaiter, A.; Paschka, P.; Zenz, T.; Rossi, M.; Döhner, K.; Bühler, A.; Böttcher, S.; Ritgen, M.; Kneba, M.; et al. Gene mutations and treatment outcome in chronic lymphocytic leukemia: Results from the CLL8 trial. Blood 2014, 123, 3247-3254. [CrossRef] [PubMed]

85. Zenz, T.; Fröhling, S.; Mertens, D.; Döhner, H.; Stilgenbauer, S. Moving from prognostic to predictive factors in chronic lymphocytic leukaemia (CLL). Best Pr. Res. Clin. Haematol. 2010, 23, 71-84. [CrossRef] 
86. Goede, V.; Fischer, K.; Busch, R.; Engelke, A.; Eichhorst, B.; Wendtner, C.M.; Chagorova, T.; de la Serna, J.; Dilhuydy, M.-S.; Illmer, T.; et al. Obinutuzumab plus Chlorambucil in Patients with CLL and Coexisting Conditions. N. Engl. J. Med. 2014, 370, 1101-1110. [CrossRef] [PubMed]

87. Fischer, K.; Bahlo, J.; Fink, A.M.; Goede, V.; Herling, C.D.; Cramer, P.; Langerbeins, P.; von Tresckow, J.; Engelke, A.; Maurer, C.; et al. Long-term remissions after FCR chemoimmunotherapy in previously untreated patients with CLL: Updated results of the CLL8 trial. Blood 2016, 127, 208-215. [CrossRef]

88. Rossi, D.; Terzi-di-Bergamo, L.; De Paoli, L.; Cerri, M.; Ghilardi, G.; Chiarenza, A.; Bulian, P.; Visco, C.; Mauro, F.R.; Morabito, F.; et al. Molecular prediction of durable remission after first-line fludarabine-cyclophosphamide-rituximab in chronic lymphocytic leukemia. Blood 2015, 126, 1921-1924. [CrossRef]

89. Kipps, T.J.; Fraser, G.; Coutre, S.E.; Brown, J.R.; Barrientos, J.C.; Barr, P.M.; Byrd, J.C.; O’Brien, S.M.; Dilhuydy, M.-S.; Hillmen, P.; et al. Long-Term Studies Assessing Outcomes of Ibrutinib Therapy in Patients With Del(11q) Chronic Lymphocytic Leukemia. Clin. Lymphoma Myeloma Leuk. 2019, 19, 715-722.e6. [CrossRef]

90. Quijada-Álamo, M.; Hernández-Sánchez, M.; Alonso-Pérez, V.; Rodríguez-Vicente, A.E.; García-Tuñón, I.; Martín-Izquierdo, M.; Hernández-Sánchez, J.M.; Herrero, A.B.; Bastida, J.M.; San Segundo, L.; et al. CRISPR/Cas9-generated models uncover therapeutic vulnerabilities of del(11q) CLL cells to dual BCR and PARP inhibition. Leukemia 2020, 34, 1599-1612. [CrossRef]

91. Woyach, J.A.; Ruppert, A.S.; Guinn, D.; Lehman, A.; Blachly, J.S.; Lozanski, A.; Heerema, N.A.; Zhao, W.; Coleman, J.; Jones, D.; et al. BTKC481S-Mediated Resistance to Ibrutinib in Chronic Lymphocytic Leukemia. J. Clin. Oncol. 2017, 35, 1437-1443. [CrossRef]

92. Quinquenel, A.; Fornecker, L.-M.; Letestu, R.; Ysebaert, L.; Fleury, C.; Lazarian, G.; Dilhuydy, M.-S.; Nollet, D.; Guieze, R.; Feugier, P.; et al. Prevalence of BTK and PLCG2 mutations in a real-life CLL cohort still on ibrutinib after 3 years: A FILO group study. Blood 2019, 134, 641-644. [CrossRef]

93. Scarfo, L.; Bonfiglio, S.; Sutton, L.-A.; Ljungstrom, V.; Pandzic, T.; Cortese, D.; Gaidano, G.; Trentin, L.; Bonello, L.; Reda, G.; et al. BTK and PLCG2 Mutations in Patients with Chronic Lymphocytic Leukemia Relapsing on Ibrutinib: A European Research Initiative on CLL (ERIC) Study Based on Real-World Evidence. In Proceedings of the 25th Annual European Hematology Association (EHA) Congress, 11-21 June 2020.

94. Woyach, J.A.; Johnson, A.J. Targeted therapies in CLL: Mechanisms of resistance and strategies for management. Blood 2015, 126, 471-477. [CrossRef]

95. Gángó, A.; Alpár, D.; Galik, B.; Marosvári, D.; Kiss, R.; Fésüs, V.; Aczél, D.; Eyüpoglu, E.; Nagy, N.; Nagy, Á.; et al. Dissection of subclonal evolution by temporal mutation profiling in chronic lymphocytic leukemia patients treated with ibrutinib. Int. J. Cancer 2020, 146, 85-93. [CrossRef]

96. Woyach, J.; Huang, Y.; Rogers, K.; Bhat, S.A.; Grever, M.R.; Lozanski, A.; Doong, T.-J.; Blachly, J.S.; Lozanski, G.; Jones, D.; et al. Resistance to Acalabrutinib in CLL is Mediated Primarily by BTK Mutations. Blood 2019, 134, 504. [CrossRef]

97. Puła, B.; Gołos, A.; Górniak, P.; Jamroziak, K. Overcoming Ibrutinib Resistance in Chronic Lymphocytic Leukemia. Cancers 2019, 11, 1834. [CrossRef] [PubMed]

98. George, B.; Chowdhury, S.M.; Hart, A.; Sircar, A.; Singh, S.K.; Nath, U.K.; Mamgain, M.; Singhal, N.K.; Sehgal, L.; Jain, N. Ibrutinib Resistance Mechanisms and Treatment Strategies for B-Cell Lymphomas. Cancers 2020, 12, 1328. [CrossRef] [PubMed]

99. Skånland, S.S.; Mato, A.R. Overcoming resistance to targeted therapies in chronic lymphocytic leukemia. Blood Adv. 2021, 5 , 334-343. [CrossRef]

100. Lama, T.G.; Kyung, D.; O’Brien, S. Mechanisms of ibrutinib resistance in chronic lymphocytic leukemia and alternative treatment strategies. Expert Rev. Hematol. 2020, 13, 871-883. [CrossRef] [PubMed]

101. Sedlarikova, L.; Petrackova, A.; Papajik, T.; Turcsanyi, P.; Kriegova, E. Resistance-Associated Mutations in Chronic Lymphocytic Leukemia Patients Treated with Novel Agents. Front. Oncol. 2020, 10, 894. [CrossRef] [PubMed]

102. Guièze, R.; Liu, V.M.; Rosebrock, D.; Jourdain, A.A.; Hernández-Sánchez, M.; Martinez Zurita, A.; Sun, J.; Ten Hacken, E.; Baranowski, K.; Thompson, P.A.; et al. Mitochondrial Reprogramming Underlies Resistance to BCL-2 Inhibition in Lymphoid Malignancies. Cancer Cell 2019, 36, 369-384. [CrossRef] [PubMed]

103. Tausch, E.; Close, W.; Dolnik, A.; Bloehdorn, J.; Chyla, B.; Bullinger, L.; Döhner, H.; Mertens, D.; Stilgenbauer, S. Venetoclax resistance and acquired BCL2 mutations in chronic lymphocytic leukemia. Haematologica 2019, 104, e434-e437. [CrossRef] [PubMed]

104. Blombery, P.; Anderson, M.A.; Gong, J.-N.; Thijssen, R.; Birkinshaw, R.W.; Thompson, E.R.; Teh, C.E.; Nguyen, T.; Xu, Z.; Flensburg, C.; et al. Acquisition of the Recurrent Gly101Val Mutation in BCL2 Confers Resistance to Venetoclax in Patients with Progressive Chronic Lymphocytic Leukemia. Cancer Discov. 2019, 9, 342-353. [CrossRef]

105. Blombery, P.; Thompson, E.R.; Nguyen, T.; Birkinshaw, R.W.; Gong, J.-N.; Chen, X.; McBean, M.; Thijssen, R.; Conway, T.; Anderson, M.A.; et al. Multiple BCL2 mutations cooccurring with Gly101Val emerge in chronic lymphocytic leukemia progression on venetoclax. Blood 2020, 135, 773-777. [CrossRef]

106. Buccheri, V.; Barreto, W.G.; Fogliatto, L.M.; Capra, M.; Marchiani, M.; Rocha, V. Prognostic and therapeutic stratification in CLL: Focus on 17p deletion and p53 mutation. Ann. Hematol. 2018, 97, 2269-2278. [CrossRef]

107. Ahn, I.E.; Tian, X.; Wiestner, A. Ibrutinib for Chronic Lymphocytic Leukemia with TP53 Alterations. N. Engl. J. Med. 2020, 383, 498-500. [CrossRef] 
108. Kater, A.; Kipps, T.J.; Eichhorst, B.F.; Hillmen, P.; D’Rozario, J.; Owen, C.; Assouline, S.; Lamanna, N.; Robak, T.; De la Serna, J.; et al. Five-Year Analysis of Murano Study Demonstrates Enduring Undetectable Minimal Residual Disease (UMRD) in a Subset of Relapsed/Refractory Chronic Lymphocytic Leukemia (R/R CLL) Patients (Pts) Following Fixed-Duration Venetoclax-Rituximab (VenR) Therapy (Tx). In Proceedings of the 62nd ASH Annual Meeting and Exposition, Atlanta, GA, USA, 11-14 December 2020.

109. Condoluci, A.; Terzi di Bergamo, L.; Langerbeins, P.; Hoechstetter, M.A.; Herling, C.D.; De Paoli, L.; Delgado, J.; Rabe, K.G.; Gentile, M.; Doubek, M.; et al. International prognostic score for asymptomatic early-stage chronic lymphocytic leukemia. Blood 2020, 135, 1859-1869. [CrossRef]

110. Thompson, P.A.; Tam, C.S.; O’Brien, S.M.; Wierda, W.G.; Stingo, F.; Plunkett, W.; Smith, S.C.; Kantarjian, H.M.; Freireich, E.J.; Keating, M.J. Fludarabine, cyclophosphamide, and rituximab treatment achieves long-term disease-free survival in IGHV-mutated chronic lymphocytic leukemia. Blood 2016, 127, 303-309. [CrossRef]

111. Barr, P.M.; Robak, T.; Owen, C.; Tedeschi, A.; Bairey, O.; Bartlett, N.L.; Burger, J.A.; Hillmen, P.; Coutre, S.; Devereux, S.; et al. Sustained efficacy and detailed clinical follow-up of first-line ibrutinib treatment in older patients with chronic lymphocytic leukemia: Extended phase 3 results from RESONATE-2. Haematologica 2018, 103, 1502-1510. [CrossRef]

112. Jarošová, M.; Plevová, K.; Kotašková, J.; Doubek, M.; Pospíšilová, Š. The importance of complex karyotype in prognostication and treatment of chronic lymphocytic leukemia (CLL): A comprehensive review of the literature. Leuk. Lymphoma 2019, 60, 2348-2355. [CrossRef] [PubMed]

113. Leeksma, A.C.; Baliakas, P.; Moysiadis, T.; Puiggros, A.; Plevova, K.; Van der Kevie-Kersemaekers, A.-M.; Posthuma, H.; Rodriguez-Vicente, A.E.; Tran, A.N.; Barbany, G.; et al. Genomic arrays identify high-risk chronic lymphocytic leukemia with genomic complexity: A multi-center study. Haematologica 2021, 106, 87-97. [CrossRef] [PubMed]

114. Baliakas, P.; Jeromin, S.; Iskas, M.; Puiggros, A.; Plevova, K.; Nguyen-Khac, F.; Davis, Z.; Rigolin, G.M.; Visentin, A.; Xochelli, A.; et al. Cytogenetic complexity in chronic lymphocytic leukemia: Definitions, associations, and clinical impact. Blood 2019, 133, 1205-1216. [CrossRef]

115. Visentin, A.; Bonaldi, L.; Rigolin, G.M.; Mauro, F.R.; Martines, A.; Frezzato, F.; Imbergamo, S.; Scomazzon, E.; Pravato, S.; Bardi, M.A.; et al. The combination of complex karyotype subtypes and IGHV mutational status identifies new prognostic and predictive groups in chronic lymphocytic leukaemia. Br. J. Cancer 2019, 121, 150-156. [CrossRef]

116. Puiggros, A.; Collado, R.; Calasanz, M.J.; Ortega, M.; Ruiz-Xivillé, N.; Rivas-Delgado, A.; Luño, E.; González, T.; Navarro, B.; García-Malo, M.; et al. Patients with chronic lymphocytic leukemia and complex karyotype show an adverse outcome even in absence of TP53/ATM FISH deletions. Oncotarget 2017, 8, 54297-54303. [CrossRef]

117. Baliakas, P.; Iskas, M.; Gardiner, A.; Davis, Z.; Plevova, K.; Nguyen-Khac, F.; Malcikova, J.; Anagnostopoulos, A.; Glide, S.; Mould, S.; et al. Chromosomal translocations and karyotype complexity in chronic lymphocytic leukemia: A systematic reappraisal of classic cytogenetic data. Am. J. Hematol. 2014, 89, 249-255. [CrossRef] [PubMed]

118. O’Brien, S.; Furman, R.R.; Coutre, S.; Flinn, I.W.; Burger, J.A.; Blum, K.; Sharman, J.; Wierda, W.; Jones, J.; Zhao, W.; et al. Single-agent ibrutinib in treatment-naïve and relapsed/refractory chronic lymphocytic leukemia: A 5-year experience. Blood 2018, 131, 1910-1919. [CrossRef]

119. Thompson, P.A.; O’Brien, S.M.; Wierda, W.G.; Ferrajoli, A.; Stingo, F.; Smith, S.C.; Burger, J.A.; Estrov, Z.; Jain, N.; Kantarjian, H.M.; et al. Complex karyotype is a stronger predictor than del(17p) for an inferior outcome in relapsed or refractory chronic lymphocytic leukemia patients treated with ibrutinib-based regimens. Cancer 2015, 121, 3612-3621. [CrossRef] [PubMed]

120. Byrd, J.C.; Harrington, B.; O’Brien, S.; Jones, J.A.; Schuh, A.; Devereux, S.; Chaves, J.; Wierda, W.G.; Awan, F.T.; Brown, J.R.; et al. Acalabrutinib (ACP-196) in Relapsed Chronic Lymphocytic Leukemia. N. Engl. J. Med. 2016, 374, 323-332. [CrossRef] [PubMed]

121. Al-Sawaf, O.; Lilienweiss, E.; Bahlo, J.; Robrecht, S.; Fink, A.-M.; Patz, M.; Tandon, M.; Jiang, Y.; Schary, W.; Ritgen, M.; et al. High efficacy of venetoclax plus obinutuzumab in patients with complex karyotype and chronic lymphocytic leukemia. Blood 2020, 135, 866-870. [CrossRef]

122. Mato, A.R.; Thompson, M.; Allan, J.N.; Brander, D.M.; Pagel, J.M.; Ujjani, C.S.; Hill, B.T.; Lamanna, N.; Lansigan, F.; Jacobs, R.; et al. Real-world outcomes and management strategies for venetoclax-treated chronic lymphocytic leukemia patients in the United States. Haematologica 2018, 103, 1511-1517. [CrossRef]

123. Anderson, M.A.; Tam, C.; Lew, T.E.; Juneja, S.; Juneja, M.; Westerman, D.; Wall, M.; Lade, S.; Gorelik, A.; Huang, D.C.S.; et al. Clinicopathological features and outcomes of progression of CLL on the BCL2 inhibitor venetoclax. Blood 2017, 129, 3362-3370. [CrossRef]

124. Woyach, J.A.; Blachly, J.S.; Rogers, K.A.; Bhat, S.A.; Jianfar, M.; Lozanski, G.; Weiss, D.M.; Andersen, B.L.; Gulrajani, M.; Frigault, M.M.; et al. Acalabrutinib plus Obinutuzumab in Treatment-Naïve and Relapsed/Refractory Chronic Lymphocytic Leukemia. Cancer Discov. 2020, 10, 394-405. [CrossRef]

125. Goldstein, D.; Beckwith, K.A.; Miller, C.; Huang, Y.; Abruzzo, L.V.; Bhat, S.A.; Bond, D.A.; Byrd, J.C.; Grever, M.R.; Heerema, N.A.; et al. Increasing Karyotypic Complexity Predicts Outcomes in Patients with Chronic Lymphocytic Leukemia Treated with Ibrutinib. Blood 2020, 136, 2-3. [CrossRef]

126. Kreuzer, K.-A.; Furman, R.R.; Stilgenbauer, S.; Dubowy, R.L.; Kim, Y.; Munugalavadla, V.; Lilienweiss, E.; Reinhardt, H.C.; Cramer, P.; Eichhorst, B.; et al. The impact of complex karyotype on the overall survival of patients with relapsed chronic lymphocytic leukemia treated with idelalisib plus rituximab. Leukemia 2020, 34, 296-300. [CrossRef] [PubMed] 
127. Villamor, N.; Conde, L.; Martínez-Trillos, A.; Cazorla, M.; Navarro, A.; Beà, S.; López, C.; Colomer, D.; Pinyol, M.; Aymerich, M.; et al. NOTCH1 mutations identify a genetic subgroup of chronic lymphocytic leukemia patients with high risk of transformation and poor outcome. Leukemia 2013, 27, 1100-1106. [CrossRef] [PubMed]

128. Balatti, V.; Bottoni, A.; Palamarchuk, A.; Alder, H.; Rassenti, L.Z.; Kipps, T.J.; Pekarsky, Y.; Croce, C.M. NOTCH1 mutations in CLL associated with trisomy 12. Blood 2012, 119, 329-331. [CrossRef]

129. Bo, M.D.; Del Principe, M.I.; Pozzo, F.; Ragusa, D.; Bulian, P.; Rossi, D.; Capelli, G.; Rossi, F.M.; Niscola, P.; Buccisano, F.; et al. NOTCH1 mutations identify a chronic lymphocytic leukemia patient subset with worse prognosis in the setting of a rituximab-based induction and consolidation treatment. Ann. Hematol. 2014, 93, 1765-1774. [CrossRef]

130. Jeromin, S.; Weissmann, S.; Haferlach, C.; Dicker, F.; Bayer, K.; Grossmann, V.; Alpermann, T.; Roller, A.; Kohlmann, A.; Haferlach, T.; et al. SF3B1 mutations correlated to cytogenetics and mutations in NOTCH1, FBXW7, MYD88, XPO1 and TP53 in 1160 untreated CLL patients. Leukemia 2014, 28, 108-117. [CrossRef]

131. Rossi, D.; Rasi, S.; Fabbri, G.; Spina, V.; Fangazio, M.; Forconi, F.; Marasca, R.; Laurenti, L.; Bruscaggin, A.; Cerri, M.; et al. Mutations of NOTCH1 are an independent predictor of survival in chronic lymphocytic leukemia. Blood 2012, 119, 521-529. [CrossRef]

132. Del Giudice, I.; Rossi, D.; Chiaretti, S.; Marinelli, M.; Tavolaro, S.; Gabrielli, S.; Laurenti, L.; Marasca, R.; Rasi, S.; Fangazio, M.; et al. NOTCH1 mutations in +12 chronic lymphocytic leukemia (CLL) confer an unfavorable prognosis, induce a distinctive transcriptional profiling and refine the intermediate prognosis of +12 CLL. Haematologica 2012, 97, 437-441. [CrossRef]

133. Weissmann, S.; Roller, A.; Jeromin, S.; Hernández, M.; Abáigar, M.; Hernández-Rivas, J.M.; Grossmann, V.; Haferlach, C.; Kern, W.; Haferlach, T.; et al. Prognostic impact and landscape of NOTCH1 mutations in chronic lymphocytic leukemia (CLL): A study on 852 patients. Leukemia 2013, 27, 2393-2396. [CrossRef]

134. Nadeu, F.; Delgado, J.; Royo, C.; Baumann, T.; Stankovic, T.; Pinyol, M.; Jares, P.; Navarro, A.; Martín-García, D.; Beà, S.; et al. Clinical impact of clonal and subclonal TP53, SF3B1, BIRC3, NOTCH1, and ATM mutations in chronic lymphocytic leukemia. Blood 2016, 127, 2122-2130. [CrossRef] [PubMed]

135. Estenfelder, S.; Tausch, E.; Robrecht, S.; Bahlo, J.; Goede, V.; Ritgen, M.; van Dongen, J.J.; Langerak, A.W.; Fingerle-Rowson, G.; Kneba, M.; et al. Gene Mutations and Treatment Outcome in the Context of Chlorambucil (Clb) without or with the Addition of Rituximab (R) or Obinutuzumab (GA-101, G) - Results of an Extensive Analysis of the Phase III Study CLL11 of the German CLL Study Group. Blood 2016, 128, 3227. [CrossRef]

136. Lee, J.; Wang, Y.L. Prognostic and Predictive Molecular Biomarkers in Chronic Lymphocytic Leukemia. J. Mol. Diagn. 2020, 22, 1114-1125. [CrossRef] [PubMed]

137. Molica, S. Chronic lymphocytic leukemia prognostic models in real life: Still a long way off. Expert Rev. Hematol. 2021, 1-5. [CrossRef]

138. Kreuzberger, N.; Damen, J.A.; Trivella, M.; Estcourt, L.J.; Aldin, A.; Umlauff, L.; Vazquez-Montes, M.D.; Wolff, R.; Moons, K.G.; Monsef, I.; et al. Prognostic models for newly-diagnosed chronic lymphocytic leukaemia in adults: A systematic review and meta-analysis. Cochrane Database Syst. Rev. 2020, 7, CD012022. [CrossRef]

139. Baliakas, P.; Mattsson, M.; Stamatopoulos, K.; Rosenquist, R. Prognostic indices in chronic lymphocytic leukaemia: Where do we stand how do we proceed? J. Intern. Med. 2016, 279, 347-357. [CrossRef]

140. Delgado, J.; Doubek, M.; Baumann, T.; Kotaskova, J.; Molica, S.; Mozas, P.; Rivas-Delgado, A.; Morabito, F.; Pospisilova, S.; Montserrat, E. Chronic lymphocytic leukemia: A prognostic model comprising only two biomarkers (IGHV mutational status and FISH cytogenetics) separates patients with different outcome and simplifies the CLL-IPI. Am. J. Hematol. 2017, 92, 375-380. [CrossRef] [PubMed]

141. Wierda, W.G.; O’Brien, S.; Wang, X.; Faderl, S.; Ferrajoli, A.; Do, K.-A.; Garcia-Manero, G.; Cortes, J.; Thomas, D.; Koller, C.A.; et al. Multivariable Model for Time to First Treatment in Patients with Chronic Lymphocytic Leukemia. J. Clin. Oncol. 2011, 29, 4088-4095. [CrossRef]

142. Gentile, M.; Shanafelt, T.D.; Cutrona, G.; Molica, S.; Tripepi, G.; Alvarez, I.; Mauro, F.R.; Di Renzo, N.; Di Raimondo, F.; Vincelli, I.; et al. A progression-risk score to predict treatment-free survival for early stage chronic lymphocytic leukemia patients. Leukemia 2016, 30, 1440-1443. [CrossRef]

143. Baliakas, P.; Moysiadis, T.; Hadzidimitriou, A.; Xochelli, A.; Jeromin, S.; Agathangelidis, A.; Mattsson, M.; Sutton, L.-A.; Minga, E.; Scarfò, L.; et al. Tailored approaches grounded on immunogenetic features for refined prognostication in chronic lymphocytic leukemia. Haematologica 2019, 104, 360-369. [CrossRef] [PubMed]

144. Hoechstetter, M.A.; Busch, R.; Eichhorst, B.; Bühler, A.; Winkler, D.; Bahlo, J.; Robrecht, S.; Eckart, M.J.; Vehling-Kaiser, U.; Jacobs, G.; et al. Prognostic model for newly diagnosed CLL patients in Binet stage A: Results of the multicenter, prospective CLL1 trial of the German CLL study group. Leukemia 2020, 34, 1038-1051. [CrossRef] [PubMed]

145. Molica, S.; Giannarelli, D.; Levato, L.; Mirabelli, R.; Gentile, M.; Morabito, F. Assessing time to first treatment in early chronic lymphocytic leukemia (CLL): A comparative performance analysis of five prognostic models with inclusion of CLL-international prognostic index (CLL-IPI). Leuk. Lymphoma 2016, 1-4. [CrossRef] [PubMed]

146. González-Gascón-Y-Marín, I.; Muñoz-Novas, C.; Figueroa, I.; Hernández-Sánchez, M.; Rodríguez-Vicente, A.-E.; Quijada-Álamo, M.; Pérez-Carretero, C.; Moreno, C.; Collado, R.; Espinet, B.; et al. Prognosis Assessment of Early-Stage Chronic Lymphocytic Leukemia: Are We Ready to Predict Clinical Evolution without a Crystal Ball? Clin. Lymphoma Myeloma Leuk. 2020, 20, 548-555.e4. [CrossRef] [PubMed] 
147. Brander, D.M.; Rhodes, J.; Pagel, J.M.; Nabhan, C.; Tam, C.S.; Jacobs, R.; Hill, B.T.; Lamanna, N.; Lansigan, F.; Shadman, M.; et al. Applicability of the Chronic Lymphocytic Leukemia (CLL)-IPI on Patients Treated with Front-Line Ibrutinib in the Real World: The Case for New Prognostic Models. Blood 2017, 130, 1719. [CrossRef]

148. Soumerai, J.D.; Ni, A.; Xing, G.; Huang, J.; Furman, R.R.; Jones, J.; Sharman, J.P.; Hallek, M.; Adewoye, A.H.; Dubowy, R.; et al. Evaluation of the CLL-IPI in relapsed and refractory chronic lymphocytic leukemia in idelalisib phase-3 trials. Leuk. Lymphoma 2019, 60, 1438-1446. [CrossRef]

149. Molica, S.; Baumann, T.S.; Lentini, M.; Levato, L.; Delgado, J.; Montserrat, E. The BALL prognostic score identifies relapsed/refractory CLL patients who benefit the most from single-agent ibrutinib therapy. Leuk. Res. 2020, 95, 106401. [CrossRef] [PubMed]

150. Gordon, M.J.; Sitlinger, A.; Salous, T.; Alqahtani, H.; Churnetski, M.; Rivera, X.; Wisniewski, P.; Cohen, J.; Patel, K.; Shadman, M.; et al. A simplified prognostic index for chronic lymphocytic leukemia treated with ibrutinib: Results from a multicenter retrospective cohort study. Leuk. Res. 2020, 89, 106302. [CrossRef]

151. Gentile, M.; Morabito, F.; Del Poeta, G.; Mauro, F.R.; Reda, G.; Sportoletti, P.; Laurenti, L.; Coscia, M.; Herishanu, Y.; Recchia, A.G.; et al. Survival risk score for real-life relapsed/refractory chronic lymphocytic leukemia patients receiving ibrutinib. A campus CLL study. Leukemia 2021, 35, 235-238. [CrossRef]

152. Molica, S.; Baumann, T.; Giannarelli, D. Prognostic models in chronic lymphocytic leukemia patients receiving ibrutinib therapy: Results of a comparative performance analysis. Eur. J. Haematol. 2021, 106, 425-427. [CrossRef]

153. Kurtz, D.M.; Esfahani, M.S.; Scherer, F.; Soo, J.; Jin, M.C.; Liu, C.L.; Newman, A.M.; Dührsen, U.; Hüttmann, A.; Casasnovas, O.; et al. Dynamic Risk Profiling Using Serial Tumor Biomarkers for Personalized Outcome Prediction. Cell 2019, 178, 699-713.e19. [CrossRef]

154. Agius, R.; Brieghel, C.; Andersen, M.A.; Pearson, A.T.; Ledergerber, B.; Cozzi-Lepri, A.; Louzoun, Y.; Andersen, C.L.; Bergstedt, J.; Von Stemann, J.H.; et al. Machine learning can identify newly diagnosed patients with CLL at high risk of infection. Nat. Commun. 2020, 11, 363. [CrossRef] [PubMed] 